\title{
Teaching and Learning Science in Authoritative Classrooms: Teachers' Power and Students' Approval in Korean Elementary Classrooms
}

\author{
Jeong-A Lee ${ }^{1} \cdot$ Chan-Jong Kim ${ }^{1}$
}

Published online: 5 September 2017

(C) The Author(s) 2017. This article is an open access publication

\begin{abstract}
This study aims to understand interactions in Korean elementary science classrooms, which are heavily influenced by Confucianism. Ethnographic observations of two elementary science teachers' classrooms in Korea are provided. Their classes are fairly traditional teaching, which mean teacher-centered interactions are dominant. To understand the power and approval in science classroom discourse, we have adopted Critical Discourse Analysis (CDA). Based on CDA, form and function analysis was adopted. After the form and function analysis, all episodes were analyzed in terms of social distance. The results showed that both teachers exercised their power while teaching. However, their classes were quite different in terms of getting approval by students. When a teacher got students' approval, he could conduct the science lesson more effectively. This study highlights the importance of getting approval by students in Korean science classrooms.
\end{abstract}

Keywords Power-Approval · Confucianism - Korean science classroom · Critical discourse analysis $\cdot$ Form and function analysis $\cdot$ Social distance $\cdot$ Science classroom discourse

\section{Introduction}

Science classrooms are inherently political and rhetorical, in that all participants, i.e. teachers and students, possess their own powers respectively. While teachers have power in the form of authority, students have power in the form of influence. Authority is an official power and is socially sanctioned by custom, while influence is an unsanctioned power which resides with students (Erickson 1986: 136). If the authority of teachers is socially sanctioned, then it reflects on the culture of the society.

Chan-Jong Kim

chajokim@snu.ac.kr

1 Department of Earth Sci Ed, Seoul National University, Seoul 151-748, South Korea 
Previous research about East Asian classrooms has suggested that teachers' authority is highly valued in East Asia (Biggs 1996; Chan and Chan 2005; Li et al. 2007; Lee et al. 2009). In the practice of power and authority in science classrooms, major culture has a substantial influence in terms of providing social structures agreed to by participants implicitly. In East Asian countries, the pedagogical value of teachers (Leu and $\mathrm{Wu} 2005$ ), teachers' beliefs and strategies for classroom behavior management (Shin and Koh 2007), students' perceptions and preferences (Lee et al. 2009), and students' styles, behaviors, and strategies (Li et al. 2007) are heavily influenced by Confucian culture and are very different from Western countries. In this culture, challenging a teacher's idea is deemed to be impolite and students respond to teachers with attention, silence, and fear (Chan and Chan 2005).

Korea has been under the heavy influence of Confucianism from the fourteenth century to the early twentieth century during the Joseon Dynasty. After the collapse of the Joseon Dynasty in early twentieth century and the liberation from Japanese rule in 1945, there has been a gradual increase of the influence of Western culture in Korea up to the present time. However, Confucianism still permeates many cultural contexts in Korea.

This study aims to understand interactions in Korean elementary science classrooms which are heavily influenced by Confucianism. In this paper, we will provide ethnographic observation of two elementary science teachers' classrooms in Korea. We will also illustrate some modes of power which appeared in two classrooms in terms of CDA. We aim to show typical and diverse patterns of interaction using discourses from each science class in this study in terms of exercising of power.

The central questions we try to answer through the analysis of teacher-student interactions are how teachers' authority affects science classroom interactions and how teachers get the approval of their students. By investigating interactions, we aim to find unique cases and patterns of exercising power and approval in an East-Asian context. Based on these cases, we aim to discuss how to facilitate students' participation who grew up accustomed to the Korean culture.

\section{Teacher-Centered Classroom in Confucian Heritage}

Teacher-student talk is usually "asymmetrical," by which we mean one of the participants (usually the teacher) leads the interaction and has the privilege, and responsibility, of being in control (Mercer and Dawes 2008, p. 56). Traditionally, within the science classroom, the teacher's role has been viewed as teacher-centered with an emphasis on transmission of the scientific idea. In this version of teaching, students are simply viewed as empty slates that take up new information. Although school reform has been conducted, teacher-centered traditional science classroom still exists all over the world.

Especially within the Confucian tradition, teachers play the role of authority and dominate the class mainly through their talk, while students are passive receivers and more inclined to believe what the teachers say instead of trying to work out their own answers or to solve the problems by themselves (Maftoon and Shakouri 2012). Confucianism ${ }^{1}$ teaches that authority is to be honored and obeyed. The influence of Confucianism has resulted in some traditional values and one of the values is obedience to the authority (Hong and Engeström 2004). In

\footnotetext{
${ }^{1}$ In this paper, Confucianism is defined as traditional attitudes and practices existing in East Asian societies which ultimately are derived from the teachings of the Chinese philosopher Confucius (551-479 BCE) and his later followers.
} 
Confucian country, there are conditions associated with speaking, and not everyone is entitled to speak. A spoken voice is equated with seniority, authority, experience, knowledge, and expertise. As a result, listening becomes a predominant form of communication, characterized as receiver-centered communication (Yum 1988) or "non-reciprocal and passive" (Gao et al. 1996, p. 286).

The general principle of Confucianism is called samgang (the three bonds). It is an established rule governing the relationships between fathers and sons, kings and people, and husbands and wives. Their relationships are structured hierarchically. King, teacher, and father are regarded as the one body (君師父一體) in Confucianism. Like a king of a country, like a father in a family, a teacher is treated with great deference throughout the community in Confucian society. As Ferguson (2001) noted, "The most salient of Korean social rules for education is respect for the teacher" (p.23).

In this cultural context, a teacher's authority is highly valued. There is a proverb in Korea: "Don't even step on the shadow of a teacher." This is an indication of how much a teacher is respected by the entire community and teachers' high position in Korean culture. Whereas teachers' position is highly valued, students' action was daunted during the classroom interaction in Confucian heritage. And teaching is largely didactic and text-bound, with little time allowed for discussion (Kennedy 2002, p. 432). In Korean culture, students traditionally have a passive position during the class. Students listen carefully to what the teacher says, do not speak out, and think carefully of questions on matters they have not fully understood (Kim 2005).

Students in other countries such as in China behave in a similar way (Biggs 1996; Bond 1991): students answer the teacher when they are asked rather than answer voluntarily; students expect the teacher to control the classroom very naturally (Lee 2006). Ho et al. (2001, p. 43) suggested the action rules for a successful student in Confucian-heritage education as follows: First, be respectful and obedient toward teachers. Second, do not challenge their authority and run the risk of invoking their displeasure or retribution. Third, the safest strategy is to keep silent in the classroom, except when the teacher gives you an opportunity to say something. Students are not encouraged to speak out, to question and to criticize, and are unwilling to commit themselves for fear of being wrong and thus losing face (Tsui 1996). These show us how teachers get power and authority over students and why teacher-centered interaction is dominant during the class in the Confucian culture.

\section{Critical Discourse Analysis}

Critical Discourse Analysis (CDA) emerged in the late 1980s as a programmatic development in European discourse studies spearheaded by Norman Fairclough, Ruth Wodak, Teun van Dijk, and others. Since then, it has become one of the most influential and visible branches of discourse analysis (Blommaert and Bulcaen 2000). The terms Critical Linguistics (CL) and Critical Discourse Analysis (CDA) are often used interchangeably (Van Dijk 1993:31). In recent times, the term $\mathrm{CDA}$ is preferred and is used to denote the theory identified as CL (Wodak 2001). CDA is a problem-oriented social research, founded in semiotics, linguistics, and social history. It regards language as social practice (Kress 1988) and takes consideration of the context of language use to be crucial (Wodak 2001; Fairclough 2003).

It is not easy to make consistent statements about the theoretical foundation of CDA. However, the former statements about CDA show that CDA has theoretical basis on social theories and linguistics. Wodak and Meyer (2001) point out that not only epistemological 
theories but also general social theories, middle-range theories, and micro-sociological theories can be found in CDA. In the context of social theories, the approach developed by B Michel Foucault and Jürgen Habermas (see Foucault 1972; Habermas 1981) is applied to CDA. CDA also has developed out of systemic functional linguistics (Halliday 1978) social semiotics (Hodge and Kress 1991), socio-cognitive studies (Van Dijk 1993), and the discourse historical method (Wodak 1999). Especially systemic functional linguistics provided analytical methods to CDA in that SFL is profoundly concerned with the relationship between language and aspects of social life. And its approach to the linguistic analysis of texts is always oriented to the social character of texts.

Based on these backgrounds, researchers (e.g., Fairclough 2003; Weiss and Wodak 2003; Wodak and Meyer 2001) have been stressed that CDA has never been and has never attempted to provide one single or specific theory. They claim that one specific methodology is not a characteristic of research in CDA. And CDA's heterogeneity of methodological and theoretical approaches allows us methodological flexibility to the research. Although the flexibilities of CDA, it aims to analyze "opaque as well as transparent structural relationships of dominance, discrimination, power and control as manifested in language" (Wodak and Meyer 2001, p. 2). To explore how texts constructs representations of the world, social relationships, and social identities, CDA investigate the language as a cultural tool mediates relationships of power and privilege in social interactions, institutions, and bodies of knowledge (Fairclough 2003; Van Dijk 2001).

Rogers (2004) argued that CDA is very useful, in that it can describe, interpret, and explain the relationships among language and educational issues. In the field of education research, CDA has been used to uncover the hidden stories in school curriculum (e.g., Chanzanagh et al. 2011; Leung 2015) and educational policy (e.g., Larsen 2010; Taylor 2004; Vasara-Hammare et al. 2012). CDA is also used to analyze conversation between a teacher and students. Young (1992) used CDA and uncovered the distortions of communication in the traditional classroom. He discovered how the traditional classroom discourse deprived the learner of the opportunity to make a rational response to the knowledge claim by using CDA.

Although CDA has not been foregrounded in the field of science classroom discourse, critical perspectives have been adopted by several researchers. Lemke (1990) suggested analyzing how teachers and students talk science in the classroom can help us to understand how students are encouraged to accept technocracy. Hanrahan (2005) tried to show how CDA can be used to explore a way of challenging the dominant discourse in teacher-student interactions in science classrooms. She also attempts to expose the importance of interpersonal relationships in school science by CDA (Hanrahan 2006). She showed the strategic way in which an experienced science teacher who is skilled in interpersonal pedagogies goes about making science more accessible by the way she interacts with her students. Mercer and Dawes (2008) said teacher-pupil talk is usually asymmetrical in that teacher leads the interaction and has the privilege, and responsibility, of being in control. And they suggested the ways to improve the quality of talk in science classroom by understanding implicit ground rules. Maeng and Kim (2011) investigated the modalities of science teaching practice and students' pedagogic subject positioning through the linguistic features of science classroom discourse based on Bernstein's Code Theory. These researches have something in common in that they take critical viewpoints and concern hidden ideological effects in science classroom discourse.

Power is the indispensable part of CDA. CDA is centrally interested in language and power because it is usually in language that discriminatory practices are enacted; in language that unequal relations of power are constituted and reproduced (Blackledge 2005). In CDA, power 
is conceptualized both in terms of asymmetries between participants in discourse events and in terms of un-equal capacity to control how texts are produced, distributed and consumed in particular social contexts (Fairclough 1995).

\section{Method}

\section{The Participants and Data Collection}

The participants in this study are two science teachers and their students at elementary schools in Seoul, Korea. Both teachers majored in elementary science education and they each have 17 years of science teaching experience. They are members of a science teachers' group for professional development and instructors for science teacher professional development programs. They are both authors of science books for children as well. In addition, they have occasionally appeared on educational TV and video programs advocating science teaching to elementary students. Therefore, they are at ease with being recorded so this did not affect the implementation of the study.

For this study, we videotaped our science classes after securing each school's principal and homeroom teachers' approval. The sample population of the study is the 6th grade science classes of teacher A and the 5th grade science classes of teacher B. The theme of teacher A's class was volcanoes and rocks and teacher B's was weather forecasting. To reduce the teachers' and students' awkwardness, we videotaped 27 lessons of teacher A and 24 lessons of teacher B before the main data collection. For the main data, we videotaped six lessons about volcanoes and rocks given by teacher A and six lessons about weather forecasting given by teacher B. Their classes are fairly traditional teaching, which mean teacher-centered interactions are dominant.

One of the researchers observed and videotaped the science classes, took field notes, and interviewed teachers and students. This researcher has been a long-time colleague of teachers $\mathrm{A}$ and $\mathrm{B}$ and has established a good rapport with them which enabled an efficient and effective study implementation.

The recorded classes were transcribed. The transcripts were coded into four digits. The first number of the code is the order of lesson. And the other three digits are the number of turntaking in that lesson. For example, the number 1234 in the transcript means the two hundred thirty fourth turn-taking in the first lesson. To describe the classes more vividly, nonverbal expressions such as silence," hesitating, be daunted, and ignoring were analyzed. In transcription, the nonverbal expressions were marked with round bracket.

\section{Data Analysis}

We have adopted CDA to understand the power and approval in science classroom discourse. It is especially relevant to educational researchers studying the interactions between teachers and students (Rogers 2004). In this respect, CDA is regarded as the best methodology to understand power and approval in science classroom discourse.

CDA have developed out of Systemic Functional Linguistics (Halliday 1978) social semiotics (Hodge and Kress 1991), sociocognitive studies (Van Dijk 1993), and the discourse historical method (Wodak 1999). It means that there are no fixed formulas for conducting CDA. It is not an inherent flaw in the method but the way in which the research has been taken up (Rogers 2004). Therefore, the methodology of CDA implementation must be defined before it is used. 
According to Gee (2004), CDA is defined as specific empirical analyses of how form and function of language correlations themselves correlate with specific social practices. And the goal of critical discourse analysis is to explore how power may operate, rather than to demonstrate its existence (Pennycook 2001).

All discourse analysis that intends to make empirical claims is rooted in specific viewpoints about the relationship between form and function (Gee 2004). In the field of linguistics, form is designated as the structural aspects of language, such as parts of speech, types of phrases, or types of clauses (Gee 2005). Ochs et al. (1996) expanded the notion of form to include certain actions like pauses, repetitions, repairs, eye gazes, speech rates, and durations of turn taking. In this study, we adopted Ochs et al.'s notion of form to show the power relations in classroom.

Function means meaning or the communicative purpose a form carried out (Gee 2004). In this study, function was named according to the role of the forms in the discourse. If a teacher asked his students "What will be happened next step?", she is "asking" in form, and the function is "asking information." "What? What are you talking about?" It is 'asking' in form, and the function is 'criticizing'. In this way, a form can have more than one function.

Based on this stance, we conducted CDA in several stages. Firstly, we focused on the problematic situation in terms of exercising power between a teacher and students. At this stage, field notes helped to identify episodes that are salient to the research purpose. To sharpen our understanding about the situation, we transcribed all lessons with the teachers' tones, eye gaze, facial expressions, and gestures, and the responses of the students. We read and reread the transcripts while watching the videotapes and had discussions about the general discourse characteristics of each teacher in terms of power and approval. We then extracted some episodes which showed aspects of power and approval between the teacher and students, and coded these transcriptions in terms of form and function. All the steps were carried reiteratively.

After the form and function analysis all episodes were analyzed in terms of social distance (Halliday and Matthiessen 2004: Young 1992). Social distance is one way to analyze the variations social relationships in classroom discourse (e.g., Young 1992). When the interlocutors interact positively then the social distance can be interpreted to be close'. When the interlocutors are in confrontation with each other, it is interpreted to be distant.

In this research, most of informing activity such as asking, statement, replying, repetition, repairing, and rephrasing was coded as Neutral. Distant means as follows: when one of the interlocutors tried to control the discourse, confronted to each other, joined the discourse reluctantly, criticized, or was daunted. When addressees expressed their understanding, approval to the speaker, or tried to join the discourse actively, they are coded as Close. Table 1 shows the analytical framework of this research.

After analyzing social distance between teachers and students, all the functions of each episodes were plotted in 4 distinct quadrants. Horizontal axis is 'teacher and students', and vertical axis is close and distant in terms of social distance. Sometimes there are some utterances which do not really belong anywhere in distant and close. In this case, it was located neutral zone in the center. After analyzing social distance, the data is plotted in diagram. Figure 1 is the diagraming of Table 2. Using this diagram shows us social distance trend between teacher-students relation at a glance.

Triangulation establishes credibility between the researchers' interpretation of the data and the individuals who supply the data (Erlandson et al. 1993). In this research, triangulation was ensured through the analyses developed by both researchers. We then showed the tentative results of our analyses to the participants and received their opinions. Their opinions were reflected in the next analysis. These processes were continued until the researchers and the 
Table 1 Analytical Framework

\begin{tabular}{|c|c|c|c|c|}
\hline \multirow[t]{2}{*}{ Form } & \multirow[t]{2}{*}{ Function } & \multicolumn{3}{|c|}{ Social distance (S.D.) } \\
\hline & & Close (C) & Neutral $(\mathrm{N})$ & Distant (D) \\
\hline \multirow[t]{6}{*}{ Asking } & Asking information & $\mathrm{O}$ & & \\
\hline & Presenting contents of class & & $\mathrm{O}$ & \\
\hline & Verifying students' understanding & $\mathrm{O}$ & & \\
\hline & Providing a clue & $\mathrm{O}$ & & \\
\hline & Asserting superiority as an informer & & & $\mathrm{O}$ \\
\hline & Criticizing & & & $\mathrm{O}$ \\
\hline Suggesting & Asking participation & & $\mathrm{O}$ & \\
\hline \multirow[t]{5}{*}{ Replying } & Informing & & $\mathrm{O}$ & \\
\hline & Joining the discourse & $\mathrm{O}$ & & \\
\hline & Giving approval & $\mathrm{O}$ & & \\
\hline & Half-hearted participation & & & $\mathrm{O}$ \\
\hline & Reluctant participation & & & $\mathrm{O}$ \\
\hline Statement & Informing & & $\mathrm{O}$ & \\
\hline \multirow[t]{4}{*}{ Repetition } & Informing & & $\mathrm{O}$ & \\
\hline & Asking information & & $\mathrm{O}$ & \\
\hline & Giving approval & $\mathrm{O}$ & & \\
\hline & Criticizing one's reply & & & $\mathrm{O}$ \\
\hline Repairing & Informing & & $\mathrm{O}$ & \\
\hline Rephrasing & Informing & & $\mathrm{O}$ & \\
\hline \multirow[t]{3}{*}{ Commanding } & Isolating someone from the discourse & & & $\mathrm{O}$ \\
\hline & Excluding someone from the discourse & & & $\mathrm{O}$ \\
\hline & Forcing to participate & & & $\mathrm{O}$ \\
\hline Notifying & Controlling the discourse & & & $\mathrm{O}$ \\
\hline \multirow[t]{2}{*}{ Interrupting } & Joining the discourse & $\mathrm{O}$ & & \\
\hline & Stopping the participation & & & $\mathrm{O}$ \\
\hline \multirow[t]{2}{*}{ Compliance } & Accepting suggestion & $\mathrm{O}$ & & \\
\hline & Accepting command & & & $\mathrm{O}$ \\
\hline \multirow{2}{*}{ Exclamation/ Laughing } & Expressing understanding & $\mathrm{O}$ & & \\
\hline & Giving approval & $\mathrm{O}$ & & \\
\hline \multirow[t]{4}{*}{ (Silence) } & Being daunted & & & $\mathrm{O}$ \\
\hline & Controlling the discourse & & & $\mathrm{O}$ \\
\hline & Waiting participation & & $\mathrm{O}$ & \\
\hline & Refusing to join & & & $\mathrm{O}$ \\
\hline (Pause) & Waiting to fill out the sentence & $\mathrm{O}$ & & \\
\hline \multirow{2}{*}{ (Ignoring) } & Controlling the discourse & & & $\mathrm{O}$ \\
\hline & Refusing to join & & & $\mathrm{O}$ \\
\hline \multirow[t]{2}{*}{ (Hesitating) } & Being daunted & & & $\mathrm{O}$ \\
\hline & Reluctant participation & & & $\mathrm{O}$ \\
\hline (Speech rate) & Controlling the discourse & & & $\mathrm{O}$ \\
\hline
\end{tabular}

(round bracket): non-verbal

participants had come to an understanding. This collaborative analysis reduced the influence of bias and subjectivity and improved the validity of our analysis and the interpretation of results (Patton 1990; Strauss 1987).

\section{Teachers' Ways of Exercising Power in Class}

In this section, we describe two teachers in terms of exercising power on their students. Power has to do with controlling others and resisting being controlled (Tannen 1986). In science classrooms, teachers may use their power to facilitate learning or inhibit activities of students. 


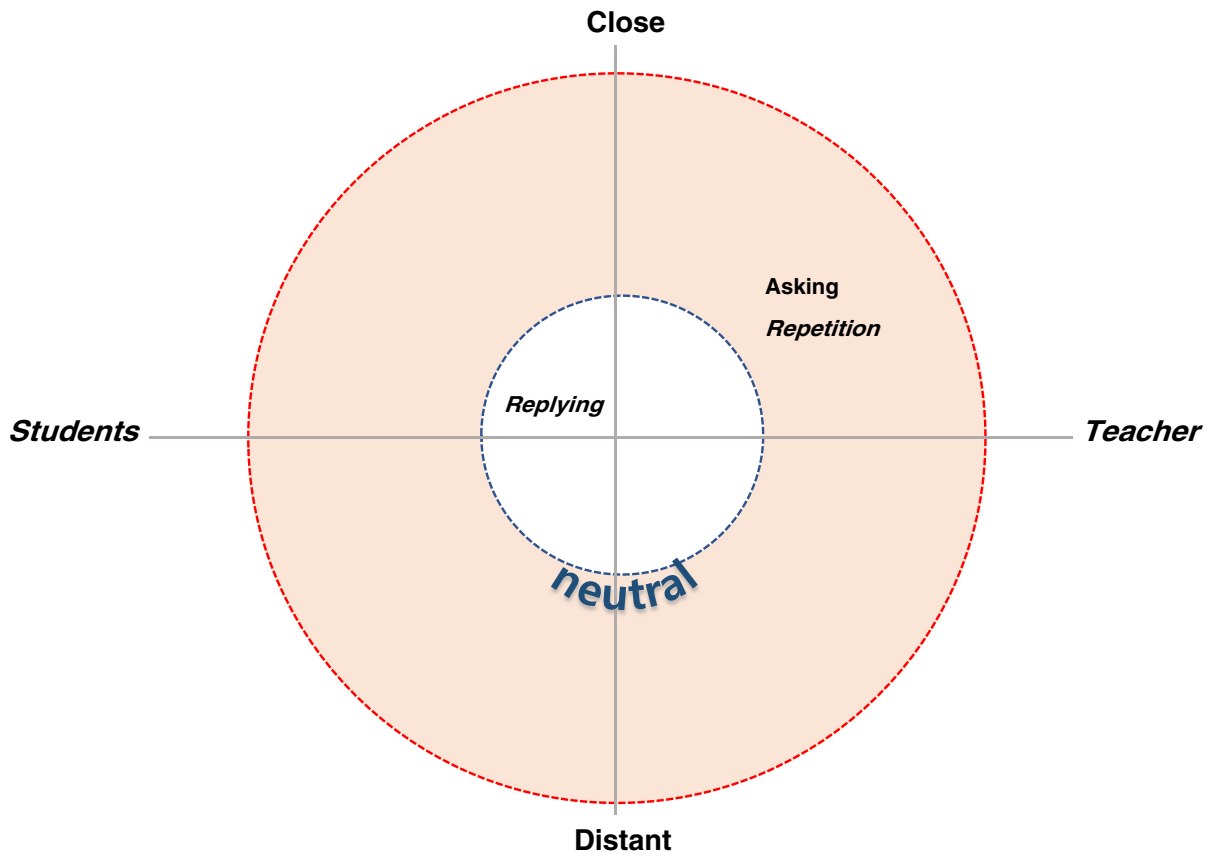

Fig. 1 Social distance between a teacher and students

Students may also use their power by keeping silent, resisting learning, or complaining to teachers. In this section, we focus on some episodes which occurred in Teacher A's and Teacher B's classrooms in terms of their exercise of power on students.

\section{Information Provider and Controlling Students' Answers: Teacher A's Episode}

Teacher A always prepares materials to provoke the interest of his students in science. He collects teaching materials and finds science documentaries related to subjects he is teaching in class.

In Episode 1, Teacher A introduces a lesson on the formation of a volcano to the students. One of his students, Eugene, interrupted the introduction because he knew the subject quite well and wanted to share his thoughts. Here, Teacher A did not want to be disturbed so he continued with his lecture. After a while, Eugene interrupted the teacher again by breaking in. Below is the transcription of this episode:

Table 2 An Example of analysis in episode

\begin{tabular}{llllll}
\hline & & Form & Function & S.D. \\
\hline 3565 & T & Do you know what I mean? Does it crack? & Asking & Verifying students' understanding & C \\
3566 & Ss & (with diffidence) Nooooo... & Replying & Informing & N \\
3567 & T & No. & Repetition & Giving approval & C \\
\hline
\end{tabular}

T: teacher, S: student, Ss: students/ S.D.: social distance, C: close, D: distant, N: neutral 


\begin{tabular}{|c|c|c|c|c|c|}
\hline \multicolumn{3}{|c|}{ Episode 1 (Teacher A) } & \multirow{2}{*}{$\begin{array}{l}\text { Form } \\
\text { Statement }\end{array}$} & \multirow{2}{*}{$\begin{array}{l}\text { Function } \\
\text { Informing }\end{array}$} & \multirow{2}{*}{$\frac{\text { S.D. }}{\mathrm{N}}$} \\
\hline 1218 & $\mathrm{~T}_{\mathrm{A}}$ & $\begin{array}{l}\text { A farmer was plowing the field. } \\
\text { And suddenly the field gave } \\
\text { off smoke! }\end{array}$ & & & \\
\hline 1219 & Eugene & Aah! I know! I know that! & Interrupting & Joining the discourse & $\mathrm{C}$ \\
\hline 1220 & $\mathrm{~T}_{\mathrm{A}}$ & $\begin{array}{l}\text { (pretending not to hear Eugene) } \\
\text { This is an unbelievable story. }\end{array}$ & $\begin{array}{l}\text { Ignoring } \\
\text { Statement }\end{array}$ & $\begin{array}{l}\text { Controlling the discourse } \\
\text { Informing }\end{array}$ & $\begin{array}{l}\mathrm{D} \\
\mathrm{N}\end{array}$ \\
\hline 1221 & Eugene & A cornfield! & Interrupting & Joining the discourse & $\mathrm{C}$ \\
\hline 1222 & $\mathrm{~T}_{\mathrm{A}}$ & $\begin{array}{l}\text { (pointing a finger at Eugene for } \\
\text { stopping his words) There was a } \\
\text { cornfield. }\end{array}$ & Repetition & $\begin{array}{l}\text { Criticizing Eugene's } \\
\text { reply }\end{array}$ & $\mathrm{D}$ \\
\hline 1223 & Eugene & $\begin{array}{l}\text { (continuing to talk to seatmate about } \\
\text { what he knows about that story) }\end{array}$ & Side talking & Informing & $\mathrm{D}$ \\
\hline 1224 & $\mathrm{~T}_{\mathrm{A}}$ & (with gentle voice) Shut up! & Commanding & $\begin{array}{l}\text { Excluding Eugene } \\
\text { from the discourse }\end{array}$ & $\mathrm{D}$ \\
\hline 1225 & $\begin{array}{l}\text { Jay/ } \\
\text { Suzie }\end{array}$ & (mimicking the teacher) Shut up! & Repetition & $\begin{array}{l}\text { Giving approval to } \\
\text { the teacher }\end{array}$ & $\mathrm{C}$ \\
\hline 1226 & $\mathrm{~T}_{\mathrm{A}}$ & $\begin{array}{l}\text { I know that you already know this } \\
\text { story. But, there are many others } \\
\text { who do not know it. If you take } \\
\text { the words out of my mouth, } \\
\text { then? (silence) }\end{array}$ & Notifying & $\begin{array}{l}\text { Controlling the } \\
\text { discourse }\end{array}$ & $\mathrm{D}$ \\
\hline 1227 & Jay & $\begin{array}{l}\text { (guessing teacher's next talk) } \\
\text { It's not funny! }\end{array}$ & Replying & $\begin{array}{l}\text { Giving approval to } \\
\text { the teacher }\end{array}$ & $\mathrm{C}$ \\
\hline 1228 & $\mathrm{~T}_{\mathrm{A}}$ & $\begin{array}{l}\text { (exchange looks with Jay) } \\
\text { It's not funny! }\end{array}$ & Repetition & $\begin{array}{l}\text { Giving approval to } \\
\text { the students }\end{array}$ & $\mathrm{C}$ \\
\hline
\end{tabular}

In episode 1, there is a struggle for dominance between Teacher A and Eugene. Controlling speaking turns is one way to get ownership in the classroom discourse for teachers (Van Dijk 1996). From [1219] to [1223], there was irregular turn-taking between Eugene and Teacher A. There were two reasons why this irregular turn-taking happened. The first reason was the teacher's implicit rejection of any attempts to share the position as information provider [1220, 1222]. The second reason was Eugene's repeated attempts to get the position of information provider [1219, 1221 and 1223]. From [1224] to [1228], the teacher retrieved his position as the only information provider in the class by directly preventing Eugene from speaking [1224, 1226, and 1228]. Moreover, the teacher firmed his position as an informer by getting alignment from Jay and Suzie [1225, and 1227]. This episode shows Teacher A stopping Eugene from participating. Meanwhile, Jay and Suzie were obedient to the teacher. After several attempts to share his thoughts, Eugene was disengaged from the discourse. Jay and Suzie gave assent to the teacher in the form of mimicking him.

$\mathrm{We}^{2}$ think Eugene interrupted our science class. The science teacher is a very good story teller, and we enjoy listening to his stories. Because Eugene was such a know-it-all, he deserved to be shamed.

$<$ Interview with Sori>

Sori, who did not participate in the discourse, also approved Teacher A as an informer during the class. Teacher A is a good informer and the students supported the teacher and excluded Eugene from the discourse.

In episode 2, Teacher A explained the process of cementation in the formation of sedimentary rocks. He used a specific strategy to request students' participation: He frequently made pauses after saying something. Whenever he made pauses, students answered or completed the teacher's sentence.

${ }^{2}$ Koreans prefer "we" rather than "I" as the subject in a sentence. 


\begin{tabular}{|c|c|c|c|c|c|}
\hline \multicolumn{3}{|c|}{ Episode 2 (Teacher A) } & \multirow{2}{*}{$\begin{array}{l}\text { Form } \\
\text { Asking }\end{array}$} & \multirow{2}{*}{$\begin{array}{l}\text { Function } \\
\begin{array}{c}\text { Verifying students' } \\
\text { understanding }\end{array}\end{array}$} & \multirow{2}{*}{$\frac{\text { S.D. }}{\mathrm{C}}$} \\
\hline 3565 & $\mathrm{~T}_{\mathrm{A}}$ & $\begin{array}{l}\text { Do you know what I mean? } \\
\text { Does it crack? }\end{array}$ & & & \\
\hline 3566 & Juno & (with diffidence) Nooooo... & Replying & Joining the discourse & $\mathrm{C}$ \\
\hline \multirow[t]{2}{*}{3567} & $\mathrm{~T}_{\mathrm{A}}$ & No. & Repetition & Giving approval & $\mathrm{C}$ \\
\hline & & $\begin{array}{l}\text { Quite the contrary, what } \\
\text { is happening in the vacant } \\
\text { spaces of the rock? }\end{array}$ & Asking & Presenting contents of class & $\mathrm{N}$ \\
\hline 3568 & Mino & It gets harder. & Replying & Joining the discourse & $\mathrm{C}$ \\
\hline \multirow[t]{3}{*}{3569} & $\mathrm{~T}_{\mathrm{A}}$ & It gets narrow. & Repairing & Informing & $\mathrm{N}$ \\
\hline & & $\begin{array}{c}\text { Then, can you guess the } \\
\text { change in the rock? }\end{array}$ & Asking & Presenting contents of class & $\mathrm{N}$ \\
\hline & & It gets...? (pause) & $\begin{array}{l}\text { Asking } \\
\quad \text { (Pause) }\end{array}$ & $\begin{array}{l}\text { Providing a clue } \\
\text { Waiting fill out }\end{array}$ & $\begin{array}{l}\mathrm{C} \\
\mathrm{C}\end{array}$ \\
\hline 3570 & Juno & Bigger. & Replying & Joining the discourse & $\mathrm{C}$ \\
\hline 3571 & Mino & (Simultaneously with Juno) Harder. & Replying & Joining the discourse & $\mathrm{C}$ \\
\hline 3572 & $\mathrm{~T}_{\mathrm{A}}$ & $\begin{array}{l}\text { (staring at Juno with angry voice) } \\
\text { Bigger? }\end{array}$ & Repetition & Criticizing Juno's reply & $\mathrm{D}$ \\
\hline 3573 & Juno & (Becomes silent) $\ldots$ & (Silence) & Being daunted & $\mathrm{D}$ \\
\hline \multirow[t]{5}{*}{3574} & $\mathrm{~T}_{\mathrm{A}}$ & It gets harder. & Repetition & $\begin{array}{l}\text { Giving approval to Mino } \\
\text { /Criticizing Juno's reply }\end{array}$ & $\begin{array}{l}\mathrm{C} / \\
\mathrm{D}\end{array}$ \\
\hline & & Do you know what I mean? & Asking & $\begin{array}{l}\text { Verifying students' } \\
\text { understanding }\end{array}$ & $\mathrm{C}$ \\
\hline & & $\begin{array}{l}\text { Generally, you guys think, } \\
\text { "Oh! It will crack." } \\
\text { No way! It does not } \\
\text { crack. Moreover, the } \\
\text { vacant space gets narrower. }\end{array}$ & Statement & Informing & $\mathrm{N}$ \\
\hline & & $\begin{array}{l}\text { What does it mean that } \\
\text { the space between grains } \\
\text { gets narrower? }\end{array}$ & Asking & $\begin{array}{l}\text { Verifying students' } \\
\text { understanding }\end{array}$ & $\mathrm{C}$ \\
\hline & & The rock becomes? (pause) & $\begin{array}{l}\text { Asking } \\
\quad \text { (Pause) }\end{array}$ & $\begin{array}{l}\text { Providing a clue } \\
\text { Waiting fill out }\end{array}$ & $\begin{array}{l}\mathrm{C} \\
\mathrm{C}\end{array}$ \\
\hline 3575 & Ss & (Simultaneously) Harder! & Replying & Joining the discourse & $\mathrm{C}$ \\
\hline \multirow[t]{3}{*}{3576} & $\mathrm{~T}_{\mathrm{A}}$ & Harder! & Repetition & Giving approval & $\mathrm{C}$ \\
\hline & & $\begin{array}{l}\text { Of course, it became } \\
\text { narrower also. }\end{array}$ & Statement & Informing & $\mathrm{N}$ \\
\hline & & $\begin{array}{l}\text { But that's not what I } \\
\text { want to hear from you, okay? }\end{array}$ & Notifying & Controlling the discourse & $\mathrm{D}$ \\
\hline
\end{tabular}

Controlling speaking turns is one way to get ownership in the classroom discourse for teachers (Van Dijk 1996). Teacher A used "pauses" frequently in his classroom conversation [3565, 3567, 3569 , and 3569]. In terms of function, the pause performed two roles. One was to notify students to participate in the discourse. And the other was to confine students' answers to the "right answer" as he wanted. Students could participate in the discourse legitimately by answering after his pause [3566, 3568, 3570, and 3575]. In other words, the teacher controlled the discourse in terms of turns at talk and content being discussed. To participate in the discourse successfully, the students tried to determine the answers that the teacher wanted to hear (Edwards and Mercer 1987).

From [3572] and [3576] we can find clues as to how the teacher controls the discourse. Mino and Juno gave different answers at the same time [3570, 3571]. However Juno's answer was not what the teacher wanted. When Juno made a wrong answer, Teacher A repeated Juno's answer in a quizzical and angry voice [3572]. This tone suggested that Juno's answer was not appropriate (Mercer 2000) and intimidated him [3573]. Moreover, the tone of the teacher has implicitly notified the class that he wanted the correct answer and he would not be happy to hear any wrong answers. This message 
seemed to be shared and accepted by the students because the students answered with exactly the "right answer" [3575]. They answered when the teacher paused and waited for participation. Through their timely participation, the momentary break which was caused by Juno's wrong answer was collapsed and the discourses were connected again. After gaining most students' right answer, Teacher A exposed a discourse rule that students had to keep in mind. This rule is "answer what the

(a)

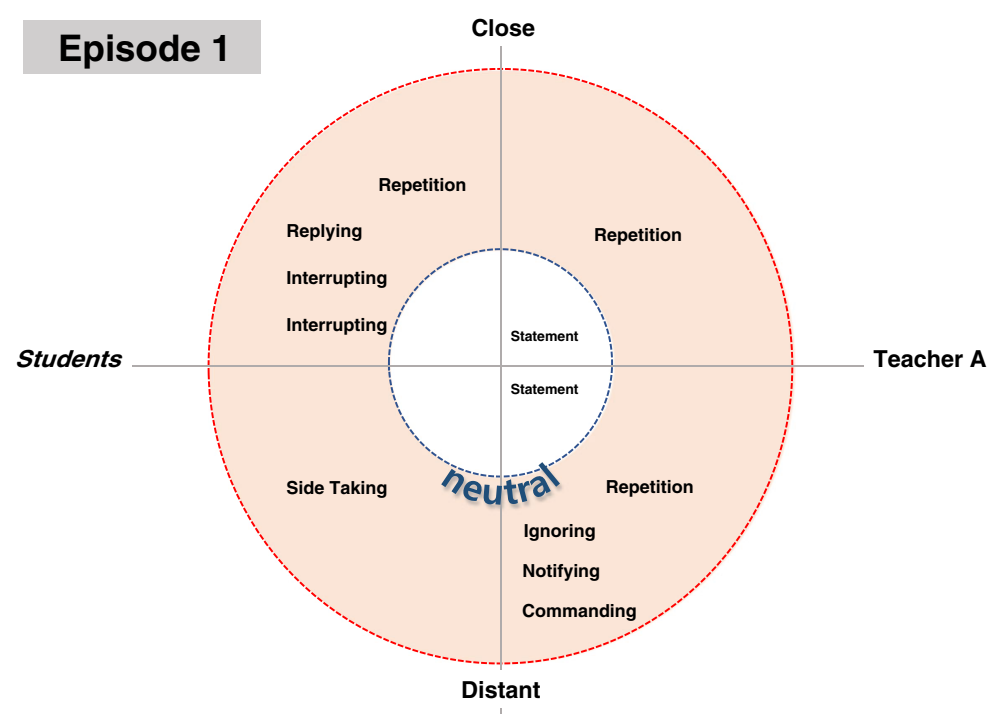

(b)

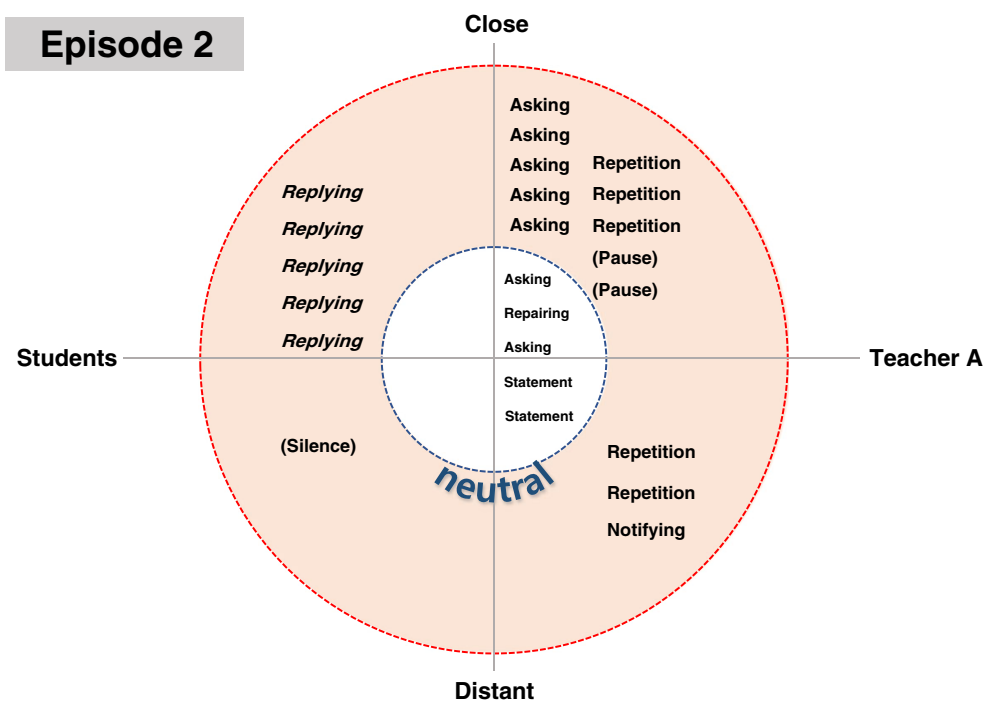

Fig. 2 Social distance of students and Teacher $\mathrm{A}$ in Episode 1 and 2 
teacher wants to hear from us" [3576]. In this way Teacher A governed the discourse not only implicitly but also explicitly. The students then tried to follow his rule.

Fig. 2 shows the social distance between students and Teacher A. Seen in Fig. 2-(a) Teacher A's comments during the episode 1 are quite distant from the students. However students' participations are quite close with Teacher A. In Fig. 2-(b), most of the teacher's asking and repetition are in the Close section. And students' all replying are in the Close section, also. It shows their social relation during the class is quite close' even some of Teacher A's discourses are in the section Distant. These diagram shows students' supporting and approval toward Teacher A during the class.

\section{Obliging Students' Participation and Open Notice of His Power: Teacher B's Episode}

In Episode 3, Teacher B controlled speaking turns during the class. He asked questions to students and waited for answers. Students whose names were called out by Teacher B mumbled or kept silent.

\begin{tabular}{|c|c|c|c|c|c|}
\hline \multicolumn{3}{|c|}{ Episode 3 (Teacher B) } & \multirow{2}{*}{$\begin{array}{l}\text { Form } \\
\text { Asking }\end{array}$} & \multirow{2}{*}{$\begin{array}{l}\text { Function } \\
\text { Presenting contents of class }\end{array}$} & \multirow{2}{*}{$\frac{\text { S.D. }}{\mathrm{N}}$} \\
\hline 6237 & $\mathrm{~T}_{\mathrm{B}}$ & $\begin{array}{l}\text { When a weather forecast be used in } \\
\text { daily life? }\end{array}$ & & & \\
\hline 6238 & Students & (silence) & (Silence) & Refusing to join & $\mathrm{D}$ \\
\hline \multirow[t]{2}{*}{6239} & $\mathrm{~T}_{\mathrm{B}}$ & (to Jiny) You! Answer me. & Commanding & Forcing to participate & $\mathrm{D}$ \\
\hline & & Do not tell him anything. & Commanding & $\begin{array}{l}\text { Isolating Jiny from the other } \\
\text { students }\end{array}$ & $\mathrm{D}$ \\
\hline 6240 & Students & (silence) & (Silence) & Being daunted & $\mathrm{D}$ \\
\hline 6241 & $\mathrm{~T}_{\mathrm{B}}$ & Stand up. & Commanding & Forcing to participate & $\mathrm{D}$ \\
\hline 6242 & Jiny & $\begin{array}{l}\text { (reply slowly with very small } \\
\text { voice) Last winter, the } \\
\text { weather forecast predicted it } \\
\text { would be snow. So, I prepared } \\
\text { gloves for a snow fight, and... }\end{array}$ & Replying & Reluctant participation & $\mathrm{D}$ \\
\hline \multirow[t]{4}{*}{6243} & $\mathrm{~T}_{\mathrm{B}}$ & (stopping Jiny’s response) Okay. & Interrupting & Stopping the participation & $\mathrm{D}$ \\
\hline & & $\begin{array}{l}\text { Because of the forecasting, } \\
\text { (changing Jiny's statements } \\
\text { into conversational form) } \\
\text { "Hey, guys! Let us have a } \\
\text { snowball fight! Prepare gloves!" }\end{array}$ & Rephrasing & Informing & $\mathrm{N}$ \\
\hline & & That can be possible. & Replying & Giving approval to Jiny & $\mathrm{C}$ \\
\hline & & $\begin{array}{l}\text { Well, if one says such a small } \\
\text { voice, I'll make him do it } \\
\text { again and again. }\end{array}$ & Notifying & Controlling the discourse & $\mathrm{D}$ \\
\hline & & Who is next? & Suggesting & Asking participation & $\mathrm{N}$ \\
\hline 6244 & Students & $\begin{array}{l}\text { (drop their heads to } \\
\text { avoid to be chosen) }\end{array}$ & (Silence) & Refusing to join & $\mathrm{D}$ \\
\hline 6245 & $\mathrm{~T}_{\mathrm{B}}$ & (to Sohee) You! & Commanding & Forcing to participate & $\mathrm{D}$ \\
\hline 6246 & Sohee & (sitting on chair looking the other way) & (Ignoring) & Refusing to join & $\mathrm{D}$ \\
\hline 6247 & $\mathrm{~T}_{\mathrm{B}}$ & (to Sohee) You! Answer me. & Commanding & Forcing to participate & $\mathrm{D}$ \\
\hline 6248 & Sohee & (still sitting) & (Ignoring) & Refusing to join & $\mathrm{D}$ \\
\hline 6249 & $\mathrm{~T}_{\mathrm{B}}$ & $\begin{array}{l}\text { (to Sohee) If you do not } \\
\text { answer, I'll make you } \\
\text { explain again and again } \\
\text { until this class finishes. }\end{array}$ & Notifying & Controlling the discourse & $\mathrm{D}$ \\
\hline 6250 & Sohee & $\begin{array}{l}\text { (stands up with a deep sigh) Well.... } \\
\text { When I was... (ellipses) }\end{array}$ & Replying & Reluctant participation & $\mathrm{D}$ \\
\hline
\end{tabular}


Notable forms encountered in this episode were asking and commanding' by Teacher B and silence and ignoring' by the students. Whenever the teacher asked [6237, 6243], the students refused to join by keeping silent and/or averting the eyes [6238, 6244, 6246, and 6248]. To induce the students' participation, the teacher called on some students and commanded them to answer [6239, 6241, 6245, and 6247]. This situation is not typical in Confucianism-influenced classrooms (Chan and Chan 2005). Students hesitated to participate in the discourse and the teacher's monologs frequently occurred during classes. To induce students' participation, Teacher B first selected one student, Jiny, to answer [6242]. Jiny accepted the teacher's demand to answer. Therefore, there was not explicit tension between Teacher B and Jiny. However, when Sohee refused the teacher's request, a conflict occurred between them. Sohee averted her eyes from the teacher's eyes even after she was repeatedly called upon by Teacher B [6245-6248]. Her silence caused a tension between her and Teacher B. This tension was diminished by the teacher's announcement [6249].

In the aspect of form Teacher B's utterance [6249] was coding notifying. However the function of this sentence was controlling the discourse by showing his power to students. Finally, Sohee participated in the discourse reluctantly and the teacher achieved his purpose. In this way, Teacher B attained students' participation by using his power as a teacher.

Exemplary students like Minsol or Minhee answer the teacher. They get good marks in return for their answers. It is natural to talk if I know something. But it is not easy. Other friends might misunderstand me as arrogant. So usually I don't answer before teachers ask me to do so. $<$ Interview with Jiny>

I hate the ones who answer the teachers to flatter them. I really hate to answer. It makes me lose face.

$<$ Interview with Sohee $>$

These interviews showed they were not aligned with the teacher. Jiny's interview showed that her volunteered participation could be interpreted to other students as arrogance or flattery in order to gain a good mark. Her concern was supported by Sohee's interview. Sohee showed a negative opinion about answering the teacher. Due to their negative views about answering in class, they wanted to avoid answering the teacher during class. Although they did answer in this class, they had been selected by the teacher to answer, so their participation should not be interpreted as an alignment with the teacher. In this way, Teacher B had trouble leading the discourse in the absence of the students' alignment. As seen in the interviews with Jiny and Sohee, there was a sense of solidarity among students not to speak to the teacher.

Figure 3 shows students and Teacher B are in conflict during the class. Notable trait in terms of social distance between students and Teacher B was weighted toward the section Distant. Teacher B used commanding, notifying and interrupting to control the students. And students confronted with silence, ignoring and reluctant replying. Silence is an effective mean to emasculate a teacher's power (Alpert 1991; Candela 1999ma). It means students' resisting to being controlled by Teacher B. They were using their power to Teacher B in forms of influence (Erickson 1986). And Teacher B's power did not work well during the class.

\section{Success/Failure to get Approval}

According to a famous Chinese Confucian, Mencius (Mengzi), in order to govern a country, a king has to obtain "cheonmyeong" which means "the will of Heaven". Cheonmyeong cannot 


\section{Episode 3}

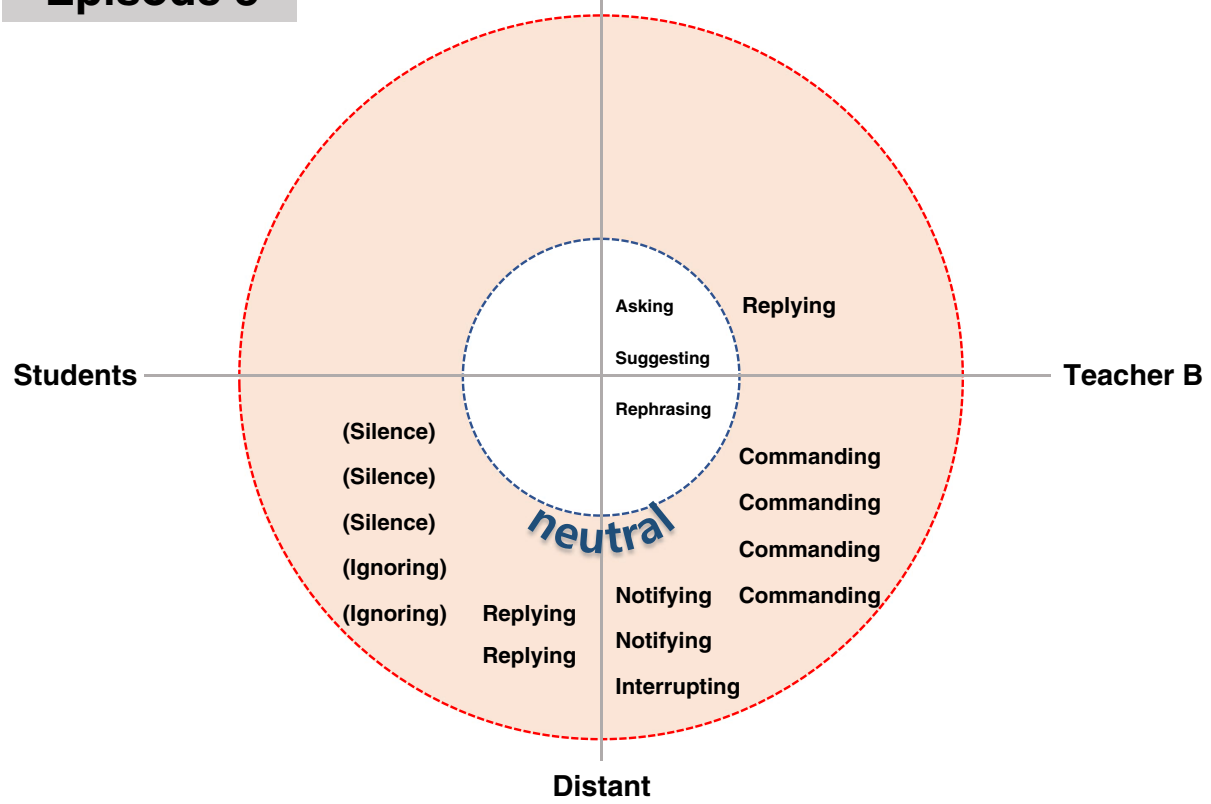

Fig. 3 Social distance of students and Teacher B in Episode 3

be achieved without the approval of the people (Park 2005). The approval of the people empowers the king to govern the country. A king pays regard to his people. On the other hand, it is proper for the people to obey a king. The people view the king as being empowered from Heaven. Giving offense to a king is giving offense to the will of the Heaven. Therefore, the people have a feeling of awe toward a king.

In this section, we examine teachers' practice in terms of approval from their students. We analyze their practice in terms of the Confucian idea of the people's approval of the king in order to understand the teachers' authority based on the students' compliance.

In Teacher A's episode, we found some characteristics which contributed to his obtaining approval from the students. In Teacher B's episode, we also found some components which hinder him in getting approval from the students.

\section{Success in Getting Approval from Students: Teacher A's Episodes}

Speech tempo is critical for determining who will be included or excluded from the ongoing classroom conversation (Bowers and Flinders 1990). Some of the strategies Teacher A uses in his class are intentionally pretending to be deaf or changing the tempo of his speech.

Teacher A gave information about the height of Mt. Baekdu. He uttered the height so quickly that students could not understand the information [4705, 4706]. Then he ignored Minho's request to repeat the information [4707]. He provided information about Mt. Everest very quickly again [4709], and students still could not understand [4710]. In spite of student requests 
[4710], he did not repeat. He just smiled and looked around at the students [4711]. After Jay's additional request, he enunciated the height of Mt. Everest very slowly. And he made the students aware of he was the one who knew the information [4713].

\begin{tabular}{|c|c|c|c|c|c|}
\hline \multicolumn{3}{|c|}{ Episode 4 (Teacher A) } & \multirow{2}{*}{$\frac{\text { Form }}{\text { Asking }}$} & \multirow{2}{*}{$\begin{array}{l}\text { Function } \\
\text { Presenting } \\
\text { contents of } \\
\text { class }\end{array}$} & \multirow{2}{*}{$\frac{\text { S.D. }}{\mathrm{N}}$} \\
\hline 4701 & $\mathrm{~T}_{\mathrm{A}}$ & $\begin{array}{l}\text { How much does the } \\
\text { temperature drop } \\
\text { per kilometer? }\end{array}$ & & & \\
\hline 4702 & Eugene & $6.3^{\circ}$ Celsius. & Replying & Joining the discourse & $\mathrm{C}$ \\
\hline \multirow[t]{2}{*}{4703} & $\mathrm{~T}_{\mathrm{A}}$ & It is $6.3^{\circ}$ Celsius. & Repetition & Giving approval & $\mathrm{C}$ \\
\hline & & $\begin{array}{l}\text { Then what is the height } \\
\text { of the Mt. Baekdu? }\end{array}$ & Asking & Presenting contents of class & $\mathrm{N}$ \\
\hline 4704 & Eugene & (Mumbling) & (Hesitating) & Being daunted & $\mathrm{D}$ \\
\hline 4705 & $\mathrm{~T}_{\mathrm{A}}$ & $\begin{array}{l}\text { It is (very quickly) two } \\
\text { thousand seven hundred } \\
\text { forty-four meters. }\end{array}$ & (Speed) Replying & $\begin{array}{l}\text { Controlling the discourse } \\
\text { Informing }\end{array}$ & $\begin{array}{l}\mathrm{D} \\
\mathrm{N}\end{array}$ \\
\hline 4706 & Minho & $\begin{array}{l}\text { (too fast to hear and ask back) } \\
\text { What? Two thousand? }\end{array}$ & Asking & Asking information & $\mathrm{C}$ \\
\hline \multirow[t]{2}{*}{4707} & $\mathrm{~T}_{\mathrm{A}}$ & (keeps talking without stop) & (Ignoring) & Controlling the discourse & $\mathrm{D}$ \\
\hline & & $\begin{array}{l}\text { Then it goes down about } \\
\text { eighteen degrees, eh? }\end{array}$ & Statement & Informing & $\mathrm{N}$ \\
\hline 4708 & Students & (Smile assenting) Wow $\sim$ ! & Exclamation & Expressing understanding & $\mathrm{C}$ \\
\hline \multirow[t]{3}{*}{4709} & $\mathrm{~T}_{\mathrm{A}}$ & Do you understand? & Asking & $\begin{array}{l}\text { Verifying students' } \\
\text { understanding }\end{array}$ & $\mathrm{C}$ \\
\hline & & It is nothing. The height & Statement (Speed) & Informing & $\mathrm{N}$ \\
\hline & & $\begin{array}{l}\text { of Mt. Everest is (very } \\
\text { quickly) } \\
\text { eight thousand eight hundred } \\
\text { forty-eight meters. }\end{array}$ & & Controlling information & $\mathrm{D}$ \\
\hline 4710 & Students & $\begin{array}{l}\text { (too fast to hear and ask back) } \\
\text { What? }\end{array}$ & Asking & Asking information & $\mathrm{C}$ \\
\hline 4711 & $\mathrm{~T}_{\mathrm{A}}$ & $\begin{array}{l}\text { (Smiling and silent while } \\
\text { looking around at the students } \\
\text { and putting hands on his waist) }\end{array}$ & (Silence) & Controlling the discourse & $\mathrm{D}$ \\
\hline 4712 & Jay & $\begin{array}{l}\text { (asking back) Eight thousand } \\
\text { what? }\end{array}$ & Asking & Asking information & $\mathrm{C}$ \\
\hline \multirow[t]{3}{*}{4713} & $\mathrm{~T}_{\mathrm{A}}$ & (Accentuating very slowly) & (Speed) Replying & Controlling the discourse & $\mathrm{D}$ \\
\hline & & $\begin{array}{l}\text { eight thousand - eight hundred } \\
\text { - forty - eight meters. }\end{array}$ & & Informing & $\mathrm{N}$ \\
\hline & & $\begin{array}{l}\text { (Pointing at Jay) Did not you } \\
\text { know that yet? }\end{array}$ & Asking & $\begin{array}{l}\text { Asserting superiority as an } \\
\text { informer }\end{array}$ & $\mathrm{D}$ \\
\hline
\end{tabular}

These sequences of events led students to increasing reliance on the teacher. He succeeded in getting his students' attention through these practices. Through these processes students were placed in a situation of information-reliance during the class (Jones and Gerard 1967). According to Foucault (1980), knowledge creates power, and power is exercised by knowledge. In the teaching-learning process, most teachers have more knowledge than their students. This allows the teacher to take the initiative in class (Erickson 1986). In this episode, Teacher A demonstrated his superior knowledge and dominated his position as an informer by asserting his superiority over the students in knowledge [4713]. He controlled information and exercised his knowledge power on all the students.

$\mathrm{He}$ is really knowledgeable. Every time I ask something, he gives a clue! He knows anything and everything about science. Well... He is a little scary because he is very stern. But I like him because he knows a lot and he is an interesting person. 


\section{$<$ Interview with Jay $>$}

As seen from episode 4, the teacher strategically showed students his superior knowledge. He controlled the tempo of speech and when he gave information. These strategies enabled him to get the students' approval as the most knowledgeable one in the class.

Teacher A is a good storyteller and explains details well. He made unfamiliar information easy for the students to understand. In this episode 5 the purpose of this teaching was the difference of the shape of volcano compare to mountain. Teacher A used the shape of volcanoes by talking a TV documentary which he watched before. In this documentary, the volcano was formed in the middle of afield, so students could get to know easily about the shape of volcano.

\begin{tabular}{|c|c|c|c|c|c|}
\hline \multicolumn{3}{|c|}{ Episode 5 (Teacher A) } & \multirow{2}{*}{ Form } & \multirow{2}{*}{$\begin{array}{l}\text { Function } \\
\text { Informing }\end{array}$} & \multirow{2}{*}{$\frac{\text { S.D. }}{\mathrm{N}}$} \\
\hline 1230 & $\mathrm{~T}_{\mathrm{A}}$ & $\begin{array}{l}\text { The farmer was plowing } \\
\text { the field. And suddenly } \\
\text { the field gave off smoke! } \\
\text { The field got hotter and hotter. } \\
\text { He was very surprised and called } \\
\text { the police. Reporters came to the } \\
\text { field, and they recorded what } \\
\text { was happening. At first, it was } \\
\text { flat because it was a just a field. }\end{array}$ & & & \\
\hline & & Wasn't it? & Asking & $\begin{array}{l}\text { Verifying students' } \\
\text { understanding }\end{array}$ & $\mathrm{C}$ \\
\hline 1231 & Students & Yes, it was! & Replying & Giving approval & $\mathrm{C}$ \\
\hline 1232 & $\mathrm{~T}_{\mathrm{A}}$ & $\begin{array}{l}\text { Do you know what happened } \\
\text { after smoke rose? (pause) }\end{array}$ & Asking & $\begin{array}{l}\text { Presenting contents of } \\
\text { class }\end{array}$ & $\mathrm{N}$ \\
\hline 1233 & Eugene & It rose up! & Replying & Joining the discourse & $\mathrm{C}$ \\
\hline \multirow{3}{*}{1234} & $\mathrm{~T}_{\mathrm{A}}$ & (with smiling) It rose up! & Repetition & Giving approval & $\mathrm{C}$ \\
\hline & & $\begin{array}{l}\text { (Drawing a mountain peak) } \\
\text { Like this. }\end{array}$ & Statement & Informing & $\mathrm{N}$ \\
\hline & & Do you know what I mean? & Asking & $\begin{array}{l}\text { Verifying students' } \\
\text { understanding }\end{array}$ & $\mathrm{C}$ \\
\hline 1235 & Students & (with nodding) A-ha! & Exclamation & $\begin{array}{l}\text { Expressing } \\
\text { understanding }\end{array}$ & $\mathrm{C}$ \\
\hline \multirow[t]{3}{*}{1236} & $\mathrm{~T}_{\mathrm{A}}$ & $\begin{array}{l}\text { It grew about } 2000 \mathrm{~m} \text {. } \\
\text { And suddenly the peak cracked! }\end{array}$ & Statement & Informing & $\mathrm{N}$ \\
\hline & & Do you know what happened? & Asking & Presenting contents & $\mathrm{N}$ \\
\hline & & $\begin{array}{l}\text { (instantly reply) It was just } \\
\text { gone! And torrents of } \\
\text { lava poured forth! }<\text { Ellipsis }>\end{array}$ & Statement & Informing & $\mathrm{N}$ \\
\hline \multirow[t]{2}{*}{1237} & $\mathrm{~T}_{\mathrm{A}}$ & $\begin{array}{l}\text { I was at a total loss for words } \\
\text { when I watched it on TV. }\end{array}$ & Statement & Informing & $\mathrm{N}$ \\
\hline & & $\begin{array}{l}\text { So, can you induce the } \\
\text { distinctive characteristics of } \\
\text { a volcano's appearance? (pause) }\end{array}$ & Asking & $\begin{array}{l}\text { Verifying students' } \\
\text { understanding }\end{array}$ & $\mathrm{C}$ \\
\hline 1238 & Hana & One peak? & Replying & Joining the discourse & $\mathrm{C}$ \\
\hline \multirow[t]{3}{*}{1239} & $\mathrm{~T}_{\mathrm{A}}$ & Yes! It has one peak! & Repetition & Giving approval & $\mathrm{C}$ \\
\hline & & Volcanoes swell in the middle. & Statement & Informing & $\mathrm{N}$ \\
\hline & & $\begin{array}{l}\text { How about the shape of common mountains? } \\
\text { (pause) }\end{array}$ & Asking & $\begin{array}{l}\text { Presenting contents of } \\
\text { class }\end{array}$ & $\mathrm{N}$ \\
\hline 1240 & Students & (As they understand) A-ha! I got it! & Exclamation & $\begin{array}{l}\text { Expressing their } \\
\text { understanding }\end{array}$ & $\mathrm{C}$ \\
\hline \multirow[t]{2}{*}{1241} & $\mathrm{~T}_{\mathrm{A}}$ & $\begin{array}{l}\text { (Drawing mountains connected with ridge) Do } \\
\text { not they look like this? }\end{array}$ & Asking & Providing a clue & $\mathrm{C}$ \\
\hline & & They are connected like this. & Statement & Informing & $\mathrm{N}$ \\
\hline 1242 & Students & Yes, they are connected! & Repetition & Giving approval & $\mathrm{C}$ \\
\hline
\end{tabular}


In this episode, Teacher A introduced a story in a documentary film about a volcanic eruption in a corn field to his students. His plan was to explain the shape of volcanoes by comparing them to that of common mountains, and he led the students to infer the shape of the volcanoes from the story in the documentary. What was at first presented as just an interesting story [1230] eventually became an observation from which students could make an inference about the shape of volcanoes [1238]. The students could come to understand more about volcanoes gradually by themselves while listening to the teacher's talk [1238, 1240, and 1242].

In this way, Teacher A gave an easy to understand account of the shape of volcanoes to the students. Connecting science with everyday knowledge helps students' understanding (Morais et al., 2004). Explaining things well is one way for a teacher to gain students' approval (Gipps and MacGilchrist 1999).

In Episode 5, whenever Teacher A asked, students participated in the discourse. They answered his questions [1233, 1238]. They agreed with him and expressed their understanding with admiration [1231, 1235, and 1240]. There was no interruption of the teacher because the students took their turns after the teacher's question. Although Teacher A explained the shape of volcano unilaterally, there was no monolog of the teacher and students joined in the discourse by nodding, exclaiming, and answering. He is good at explaining things to the students, and his discourses were supported by the students' continuous participation.

Seen in Fig. 4-(a), Teacher A frequently uses nonverbal strategies such as silence speed and ignoring which belong to Distant section. However there are asking and repetition of Teacher A and exclamation of students which belong to Close section. In Fig. 4-(b), most of the classroom discourse are happening in Close section in terms of social distance. Teacher A asked, repeated and students correspond with exclamation, replying and repetition. All the participants of the classroom discourse are interacting in a positive stance each other.

I like science class, and I like my science teacher. He is knowledgeable and very funny. So I enjoy talking with him during classes. Sometimes he reproaches for me or others when we interrupt his talking. (With smile) We have to be really careful not to make him mad. Anyway we know when we have to answer. But I don't blame him. He is the one who leads the class. So we have to follow him.

$<$ Interview with Juno>

I didn't like science until last year. But these days, I am apt to participate in my science class very actively. My classmates also participate in science class more actively than in any other classes. Last time he brought small submarine kits, and gave them to all of us to make. He also gave us some magic kits. He always prepares something really interesting. He said he bought them with his own money and I was surprised. My friend and I now like science! $<$ Interview with Jenny>

Sometimes he scares me, because he scolds me or stares at me when I give a wrong answer. But he is a very interesting teacher. When we are bored, he always gives us something which is very funny. And he connects science with everyday experiences in my life. (With a faint smile) Sometimes I don't understand what he says. But it is okay, after class I can investigate the things I don't understand on my own.

$<$ Interview with Hana>

There were two common things that the students said about Teacher A: he is good and funny as a science teacher and he is scary. According to the students, he is a scary teacher to them rather than kind one. He is a stern teacher. Answering his question incorrectly or 
interrupting him was not tolerated. However, the students agree that he is an able science teacher. Juno's interview shows exactly the type of approval gained by the teacher expected in a Confucian culture. Juno took the teacher's role (lead the class, sets the turn taking, have superior knowledge) for granted. In Hana's interview there is another point worth noting: her passive stance in not questioning the teacher when she did not understand what the teacher said. She instead investigated by herself after class. This shows a typical understanding of the roles of student and teacher in a Confucian culture (e.g. Bond 1991; Chan and Chan 2005; Li et al. 2007). From the students' point of view, he is a scary but able teacher who teaches

(a)

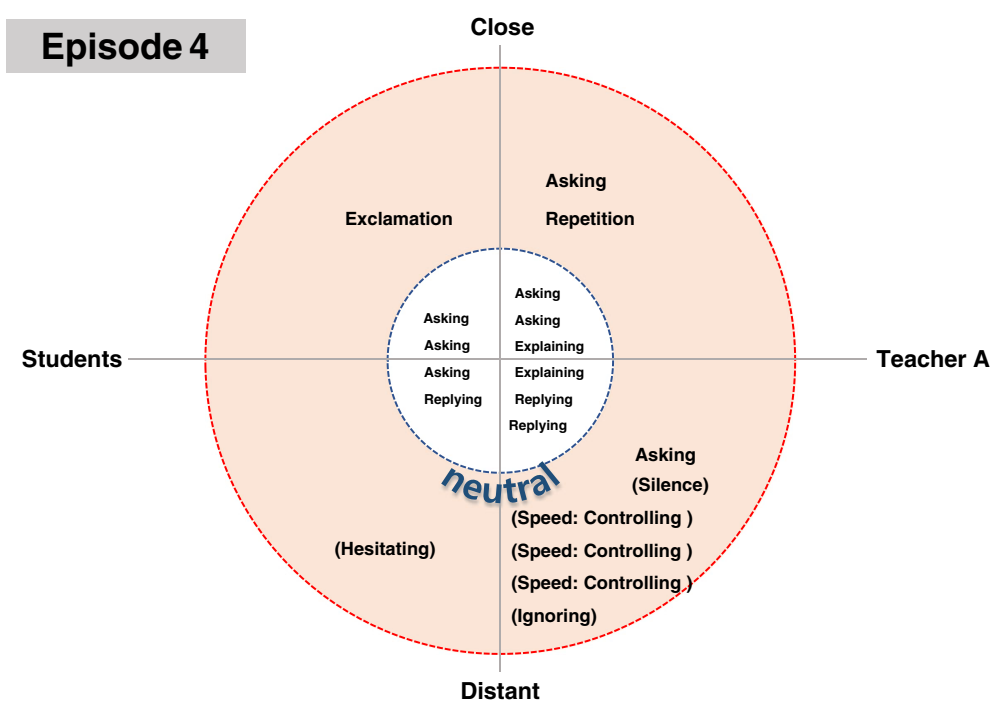

(b)

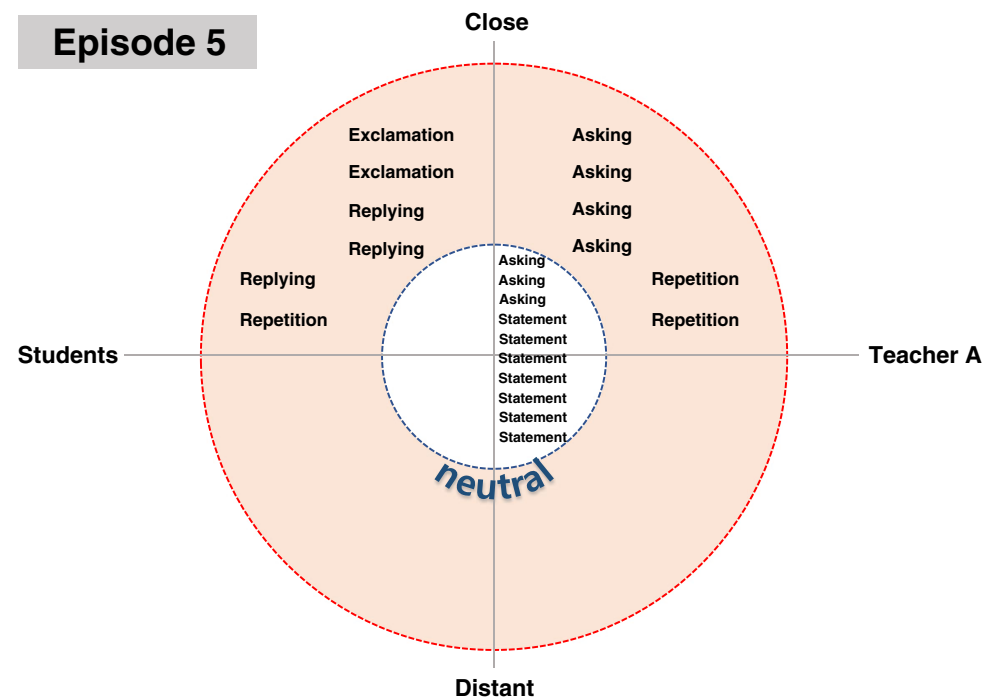

Fig. 4 Social distance of the students and Teacher A in Episode 4 and 5 
science well. He is able to use strategies within a Confucian context to encourage students to follow his methods, thereby gaining his students' approval.

Until now we described how the Teacher A exercises his power to his students during the science class. And we also described how his students internalized the teacher's way of exercising power on them and accepting it. Next we show how Teacher B failed in getting approval from his students.

\section{Failure in Getting Approval from Students: Teacher B's Episodes}

In episode 6, Teacher B told his experience to the students. The main story was "worrying that it would rain on a picnic day when he was a child." Students enjoyed the story. When Teacher B asked a question of students, a problem began. From Teacher B's point of view, Hansu's answer was not enough. From the students' view, the teacher's answer was nonsense.

\begin{tabular}{|c|c|c|c|c|c|}
\hline \multicolumn{3}{|c|}{ Episode 6 (Teacher B) } & \multirow{2}{*}{ Form } & \multirow{2}{*}{$\frac{\text { Function }}{\text { Informing }}$} & \multirow{2}{*}{$\frac{\text { S.D. }}{\mathrm{N}}$} \\
\hline 3033 & $\mathrm{~T}_{\mathrm{B}}$ & $\begin{array}{l}\text { Because I was so excited to } \\
\text { go to picnic I could not } \\
\text { sleep. I prayed, "please } \\
\text { do not rain," and asked } \\
\text { mother, "Mom, is it raining?" } \\
\text { "No. Why do not you sleep or } \\
\text { you'll oversleep tomorrow." But } \\
\text { I could not sleep. "Mom, is it } \\
\text { raining?" } \\
\text { "No. Do not worry. Just sleep! } \\
\text { PLEASE." }\end{array}$ & & & \\
\hline 3034 & Students & (laugh) & Laughing & Giving approval & $\mathrm{C}$ \\
\hline 3035 & $\mathrm{~T}_{\mathrm{B}}$ & $\begin{array}{l}\text { One hour later after going } \\
\text { to bed I asked mother again, } \\
\text { "Mom is it raining?", } \\
\text { "NO! IT IS NOT RAINING! } \\
\text { Just sleep, okay?" }\end{array}$ & Statement & Informing & $\mathrm{N}$ \\
\hline 3036 & Students & Ha-ha! & Laughing & Giving approval & $\mathrm{C}$ \\
\hline \multirow[t]{2}{*}{3037} & $\mathrm{~T}_{\mathrm{B}}$ & This is a real story. & Statement & Informing & $\mathrm{N}$ \\
\hline & & $\begin{array}{l}\text { What do children worry } \\
\text { about when they are going } \\
\text { to have a picnic? }\end{array}$ & Asking & Asking information & $\mathrm{N}$ \\
\hline 3038 & $\mathrm{~T}_{\mathrm{B}}$ & (silence) & Silence & Waiting Participation & $\mathrm{N}$ \\
\hline 3039 & $\mathrm{~T}_{\mathrm{B}}$ & What do they think? & Asking & Asking information & $\mathrm{N}$ \\
\hline 3040 & Hansu & (mumbling) Rain? & Replying & Informing & $\mathrm{N}$ \\
\hline 3041 & $\mathrm{~T}_{\mathrm{B}}$ & They think about the weather forecast. & Repairing & Informing & $\mathrm{N}$ \\
\hline 3042 & Students & $\begin{array}{l}\text { (small voice) Weather forecast? It's } \\
\text { nonsense. }\end{array}$ & Repetition & $\begin{array}{l}\text { Criticizing teacher's } \\
\text { opinion }\end{array}$ & $\mathrm{D}$ \\
\hline \multirow[t]{2}{*}{3043} & $\mathrm{~T}_{\mathrm{B}}$ & (pretending not to hear) So we'll & (Ignoring) & Controlling discourse & $\mathrm{D}$ \\
\hline & & $\begin{array}{l}\text { learn when a weather forecast } \\
\text { is used in daily life. }\end{array}$ & Statement & Informing & $\mathrm{N}$ \\
\hline 3044 & Junseo & $\begin{array}{l}\text { (with a sarcastic remark) } \\
\text { What is he saying? }\end{array}$ & Asking & Criticizing the teacher & $\mathrm{D}$ \\
\hline 3045 & & What? Just open your book. & Commanding & Forcing to participate & $\mathrm{D}$ \\
\hline 3046 & Students & (open all their own books together) & Compliance & Accepting command & $\mathrm{D}$ \\
\hline
\end{tabular}

The teacher told a story about when he was a child [3033, 3035]. His aim was to establish a rapport with students by sharing his experiences [3033, 3035]. 
I told my story to make my students interested in the weather forecast. In my view, sharing my own experience is more effective than just giving an explanation about something. They also can talk about their own experiences during class. By sharing experiences we can establish a good rapport.

$<$ Interview with Teacher B>

In the beginning, the students joined the discourse with a laugh [3034, 3036]. However, there was a disconnection between Teacher B and students. From the view point of Hansu, the teacher's story was about "worrying about rain on a picnic day" [3040]. However the teacher did not accept Hansu's idea. Instead he gave the answer to his own question [3041]. Some of the students showed active resistance to the teacher. Some of the students criticized the logical gap with a small voice [3042]. However, the teacher ignored their opinions and kept going with his explanation [3043]. At that moment, Junseo exercised power by expressing his disagreement with the teacher [3044]. Nevertheless, Teacher B urged students to learn about "weather forecasting" [3043, 3045].

Actually, from [3033] to [3035] the theme of the story was "whether it would rain or not." There was no comment about "weather forecasting" before the teacher said it [3041]. Some students pointed out the logical gap in logic, but the teacher continued to talk about weather forecasting. On the surface, Teacher B seemed to succeed in handling the discourse as he wanted. However, there were instances of the students exercising power against the teacher in such ways as disagreements with the teacher [3042] or a sarcastic remark [3044]. Their exercising power against the teacher accompanied negative emotions toward him.

I still don't agree with him (Teacher B). How about you? Do you really think that he talked about "weather forecasting"?

$<$ Interview with Hansu>

As seen from the above interview, Hansu did not accept the teacher's logic after the class and showed negative emotion toward the teacher. Although the teacher succeeded in making his students follow his command [3046], he failed to get the students' approval.

In episode 7, Teacher B wanted to show the clear sky. He continuously asked his students to look out the window. However, the students remained seated despite his continuous requests to look at the sky. The class was delayed by the teacher's request that the students join in and the students' passive attitude toward the class.

\begin{tabular}{|c|c|c|c|c|c|}
\hline \multicolumn{3}{|c|}{ Episode 7 (Teacher B) } & \multirow{3}{*}{$\begin{array}{l}\text { Form } \\
\text { Statement } \\
\text { Asking }\end{array}$} & \multirow{2}{*}{$\frac{\text { Function }}{\text { Informing }}$} & \multirow{2}{*}{$\frac{\text { S.D. }}{\mathrm{N}}$} \\
\hline 1007 & $\mathrm{~T}_{\mathrm{B}}$ & Today I could not bear to attend school. & & & \\
\hline & & Do you know why? & & Asking information & $\mathrm{N}$ \\
\hline 1008 & Sanghun & (small voice) No reason. & Replying & $\begin{array}{l}\text { Half-hearted } \\
\text { participation }\end{array}$ & $\mathrm{D}$ \\
\hline 1009 & $\mathrm{~T}_{\mathrm{B}}$ & Do you know why? & Repetition & Asking information & $\mathrm{N}$ \\
\hline 1010 & Minhee & $\begin{array}{l}\text { (guessing) Because the } \\
\text { weather was too sunny } \\
\text { to come to the school? }\end{array}$ & Replying & Joining the discourse & $\mathrm{C}$ \\
\hline \multirow{2}{*}{\multicolumn{2}{|c|}{$1011 \mathrm{~T}_{\mathrm{B}}$}} & $\begin{array}{l}\text { Wow! You are in telepathic } \\
\text { communication with me! }\end{array}$ & Exclamation & Giving approval & $\mathrm{C}$ \\
\hline & & $\begin{array}{l}\text { Look at the sky! (to the } \\
\text { student seated by the window) } \\
\text { Hey, open the curtains. }\end{array}$ & Suggesting & Asking participation & $\mathrm{N}$ \\
\hline 1012 & Students & Wow! It is clear. & Exclamation & Giving approval & $\mathrm{C}$ \\
\hline
\end{tabular}




\begin{tabular}{|c|c|c|c|c|c|}
\hline \multicolumn{3}{|c|}{ Episode 7 (Teacher B) } & \multirow{2}{*}{$\begin{array}{l}\text { Form } \\
\text { Suggesting }\end{array}$} & \multirow{2}{*}{$\begin{array}{l}\text { Function } \\
\text { Asking participation }\end{array}$} & \multirow{2}{*}{$\frac{\text { S.D. }}{\mathrm{N}}$} \\
\hline 1013 & $\mathrm{~T}_{\mathrm{B}}$ & $\begin{array}{l}\text { Look at the sky! Why } \\
\text { do not you go over } \\
\text { and look at the sky? } \\
\text { No problem. Look at the sky. }\end{array}$ & & & \\
\hline 1014 & Students & (still sitting) & (Silence) & Refusing to join & $\mathrm{D}$ \\
\hline 1015 & & Go over and see the sky! Go over, go over! & Suggesting & Asking participation & $\mathrm{N}$ \\
\hline 1016 & Students & $\begin{array}{l}\text { (Noise: some of them } \\
\text { go to the window } \\
\text { and most of them are still sitting) }\end{array}$ & (Ignoring) & Refusing to join & $\mathrm{D}$ \\
\hline 1017 & $\mathrm{~T}_{\mathrm{B}}$ & $\begin{array}{l}\text { You will not know } \\
\text { until you see the } \\
\text { sky today. }\end{array}$ & Suggesting & Asking participation & $\mathrm{N}$ \\
\hline 1018 & Students & $\begin{array}{l}\text { (turning their heads toward } \\
\text { the windows but still sitting } \\
\text { on their chair) }\end{array}$ & (Hesitating) & $\begin{array}{l}\text { Reluctant } \\
\text { participation }\end{array}$ & $\mathrm{D}$ \\
\hline \multirow[t]{2}{*}{1019} & $\mathrm{~T}_{\mathrm{B}}$ & $\begin{array}{l}\text { (pointing at the sky in the } \\
\text { window of the corridor side } \\
\text { of the room) That side is more beautiful than } \\
\text { this side. }\end{array}$ & Suggesting & Asking participation & $\mathrm{N}$ \\
\hline & & Go over and look at the sky! & Commanding & Forcing to participate & $\mathrm{D}$ \\
\hline 1020 & Students & (Noise: move toward corridor in crowds) & Compliance & Accepting command & $\mathrm{D}$ \\
\hline 1021 & & $\begin{array}{l}\text { (directly after moving into the corridor) Well, } \\
\text { come in please. }\end{array}$ & Interrupting & $\begin{array}{l}\text { Stopping the } \\
\text { participation }\end{array}$ & $\mathrm{D}$ \\
\hline 1022 & Students & $\begin{array}{l}\text { (small voice while sitting) What is he doing to } \\
\text { us? }\end{array}$ & Asking & Criticizing & $\mathrm{D}$ \\
\hline
\end{tabular}

In this episode, we find Teacher B's continuous request for students to join the discourse [1007, 1009, 1011, 1013, 1015, and 1019] and students' indifferent attitude to the discourse [1008, 1014, 1016 and 1018]. Except for Minhee's volunteered participation, the students hardly participated in the discourse [1010]. Because of this attitude by the students, the discourse was stunted.

It is notable that the teacher stopped the students from looking as soon as the students went into the corridor to see the sky [1019-1021]. Teacher B asked his students to go over and look at the sky [1019]. At first, students did not move to look at the sky. But as you seen in the paragraph of [1020], they moved to look out. However in the paragraph of [1021] the teacher asked them to sit down in a minute. It may be that he wanted to avoid further delay of the class. If the students had done what he requested in a timely fashion, this situation would not have happened. Because of the delayed participation of the students, the teacher had to make them take their seats again quickly. Because of this, the students felt their participation was meaningless. So in [1022] students are complaining about that. The prohibition of the teacher contradicted his continuous requests to participate. Teacher B's sudden interruption of the students' participation led to the students' complaints and negative emotions [1022].

Figure 5 shows the mode of social distance between students and Teacher B. They are interacting during the class, but their discourse is quite conflictive. In Fig. 5-(a) most of discourse in 'Neutral' zone. Except the neutral zone, the last of Teacher B's discourse is in the distant. The most marked characteristic in Fig. 5-(b) is most of the discourses of students are located in distant field. The students' asked, replied, and complied but they did not legitimized Teacher B. They ignored, kept silence, and hesitated to Teacher B's request to join the discourse. Here is an interview from Sanghun who showed half-hearted participation during the class. 
Well, I'm not sure whether he really wants me to join the class or not. Actually, it happens a lot in my class. At first, he tells us to do something. But he stops us as soon as we really do. $<$ Interview with Sanghun>

From the point of Sanghun, he was confused about the teacher's real intention. Because the teacher asked them to participate in the activity at first, then they were stopped in the act of doing. It has been emphasized the importance of 'the co-construction of cognitive context'

(a)

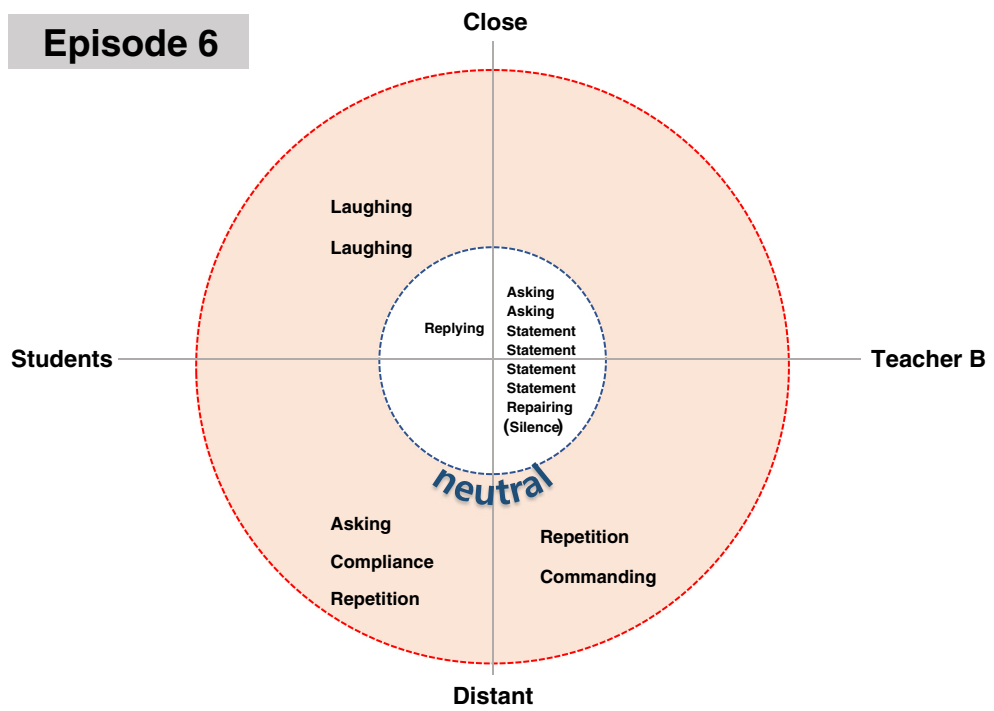

(b)

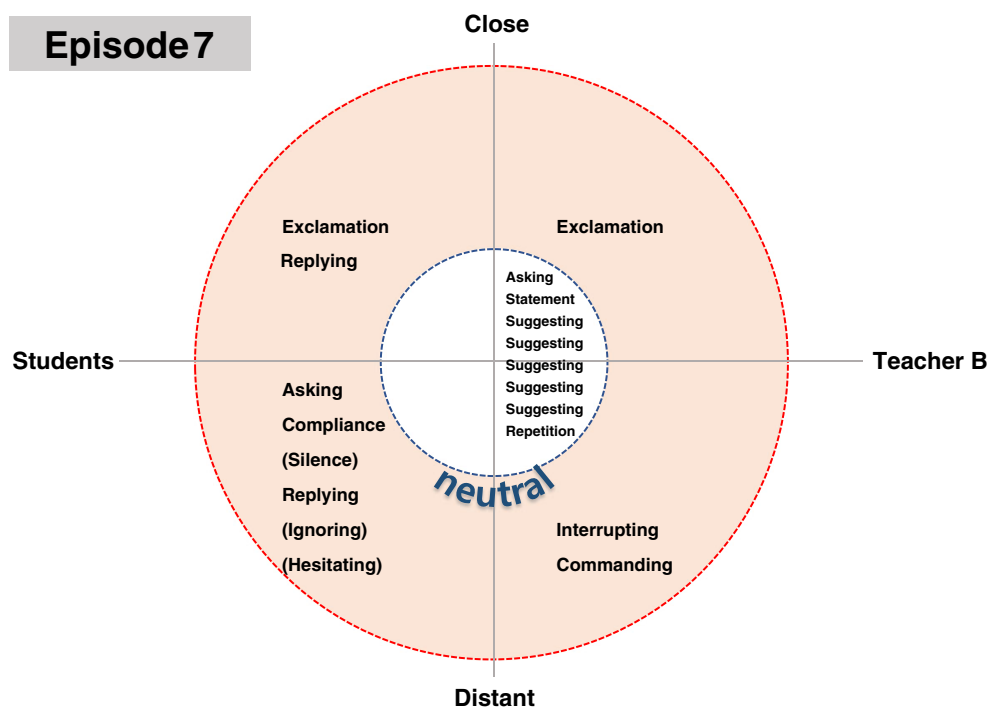

Fig. 5 Social distance between students and Teacher B in Episode 6 and 7 
between a teacher and students from advanced researches (Fullan 2001). It allows them to share common responsibility during the classroom activity and treat them as equal partner during the class. Students are aware, albeit not at the theoretic level, of when they are being treated as persons in an education al relationship and when as mere instructional objects (Young 1992: 67). Previous example shows that treating students as instructional objects contributes to alienation between a teacher and students.

These analyses and interviews showed the students' consistently negative emotions toward the teacher. Hansu and Junseo (from episode 6 and 7) were coerced into accepting the teacher's opinion. Sanghun complained that there was inconsistency in what the teacher said (from episode 7). Teacher B's unconscious practices during the class made the students resist him and he had trouble leading the class. To induce the students' participation, he had to coerce them or wait. This result shows students' approval of a teacher is not unconditional even in the schools with a Confucianism environment. Comparing the cases of Teachers A and B shows the components or characteristics of gaining students' approval. We will discuss these in the next section.

\section{Summary and Discussion}

This study was conducted to investigate the practice of power and approval in science classrooms in Korea. Historically, Korea has been a Confucian culture for more than five hundred years. Rapid westernization places Korea in a very unique context with regard to hybridization. The Western educational system and the advancement of democracy provided the idea of progressive education. However, the lasting influence of Confucianism supports the exercise of power by teachers in the classroom. In this research, we tried to understand teaching and learning science in authoritative classrooms in Korea. As conceptual tools to understand the science classroom, we utilized to the concept of power and approval of teachers and students.

Both teachers who participated in this study exercised their power while teaching. They had something in common in that they both exercised their power during class. For example, Teacher A did not allow students to share his role as an information provider. He controlled turn-taking with questions and pauses. When a student broke the discourse rule he expelled him from the discourse. Teacher B frequently forced students to join the discourse. When students refused to participate, he commanded students to join or exercised his power as an evaluator or a director.

However, their classes were quite different in terms of getting approval from students. Teacher A succeeded in obtaining approval from his students by making efforts to help students have fun and explain scientific knowledge more easily. Although they thought Teacher A was a scary teacher, students also found him to be an interesting and able science teacher. Students continuously engaged in the discourse. They nodded in excitement, filled up the teacher's incomplete sentences, and gave credit to him. Their supportive reaction helped Teacher A lead the science class as he wanted. Even when Teacher A monopolized the role of information provider in the classroom, the students accepted it. Moreover, they went to bat for him. They followed implicit discourse rules such as "answer after the teacher pauses," and they tried to give the answers that the teacher wanted.

On the contrary, Teacher B continuously had to ask for students' participation. Sometimes he waited for students' participation or answers, and sometimes he coerced them into submission. However, the students kept silent and expressed their feelings negatively. The 
more he tried to force them, the less interaction occurred. For this reason, Teacher B had trouble teaching them. Actually, there were few instances where he attempted to gain the students' approval. He continuously asked the students and coerced them into doing things. Even when the students complained about illogical developments in his discourse, he ignored them. When the students followed his directions, he changed his words and withdrew the directions. These events contributed to the negative emotions the students felt toward the teacher. The students' resistance manifested itself as silence, whispering, and blame.

Korean culture is authority-oriented and hierarchically structured due to the influence of Confucianism. And Korean students expect the teacher to know everything about a subject and to control the classroom (Lee 2006). However, this cultural background did not ensure that Korean teachers would be able to exercise their power fully. As seen in the results of this research, it was the students' approval that ensures that teachers will be able to do this. As shown in the Teacher B's case, a teacher has difficulties leading the class without students' approval. This result suggests the importance of students' approval in science teaching and learning.

Getting approval by students will be more and more important in Korean schools. On the one hand, rapid Westernization affects the entire educational system, curriculum, and teaching in Korea. And egalitarianism, which is based on human equality with respect to social and political rights and privileges, is pervasive in schools in Korea. On the other hand, Confucianism still has a great influence on school culture in Korea. As is evident from this study, students judged a teacher's authority or power by her/his practices in classes. When teachers adhere to their authority and power based on Confucianism, science teaching and learning face serious difficulties. On the contrary, when a teacher gets approval by students, authority can be exercised little restriction at all. The teacher will obtain the students' support and will be able to lead the science class.

This study suggests the importance of students' approval of teachers. We decided to use the concept of students' approval of teachers in authoritative classrooms in East Asia. This was borrowed from Mencius' philosophy that an absolute monarch's power over his people should be based on approval from them. We believe that to some extent the people's approval toward a king and students' approval toward a teacher have similarities. As the people's approval of a king is essential in ruling a country, students' approval of a teacher seems to be essential in the classroom.

Approval can be understood as students' personal acceptance of a teacher as a person who is qualified to teach them. This can occur in a classroom with a hierarchical social structure. Even though this society gives a teacher a position of power, the teacher still needs to prove her/his qualifications to students. Qualifications for approval should be explored further; however, throughout this study we can see several important attributes, such as a strong background in content knowledge, enthusiasm for better teaching (including making the class enjoyable and preparing interesting learning materials), the ability to understand students, and consistency of behavior during teaching. Getting approval requires a teacher to have various abilities in affective and cognitive, as well as interpersonal and personal domains. When a teacher succeeds in obtaining students' approval, students will voluntarily participate and the teaching discourse will not be interrupted.

In Western countries where interactions are assumed to be based on egalitarianism, researchers tend to incline to the concept of solidarity between teachers and students (Nieto 2006) rather than students' approval of a teacher. Solidarity is the feeling of reciprocal sympathy and responsibility among members of a group which promotes mutual support (Wilde 2007). In this respect, solidarity is quite different from approval because it assumes equity and mutual respect among participants. However, asymmetry between a teacher and students in terms of power still exists 
even in the classrooms of Western countries, and the concept of approval may also contribute to the understanding of the interactions between a teacher and students in Western science classroom.

The concept of students' approval of teachers suggests important implications for teacher education. We may need to go beyond the current practices of teacher preparation emphasizing science content knowledge and teaching skills. We need to transform teacher education programs to include working on how to develop meaningful relationships with students. Since getting students' approval is critical for successful science teaching, prospective teachers need to be prepared for this and teacher education programs need to reflect this need.

In a similar way, Nieto (2006) suggested some of the qualities of teachers who make a positive difference in the lives of students in multicultural society like the US. Solidarity with and empathy for their students are two of these qualities. She suggested developing teacher education programs that encourage the prospective teachers to learn more about students and their contexts of living and to respect their culture. Although Korea is culturally not so diverse, teachers still need to understand students and the influence of Confucian culture in science classroom. Teacher education programs should put more emphasis on understanding the relationship and interaction between students and teachers in culturally meaningful ways.

Open Access This article is distributed under the terms of the Creative Commons Attribution 4.0 International License (http:/creativecommons.org/licenses/by/4.0/), which permits unrestricted use, distribution, and reproduction in any medium, provided you give appropriate credit to the original author(s) and the source, provide a link to the Creative Commons license, and indicate if changes were made.

\section{References}

Alpert, B. (1991). Students' resistance in the classroom. Anthropology \& Education Quarterly, 22, 350-366.

Biggs, J. B. (1996). Learning, schooling and socialization: A Chinese solution to a western problem. In S. Lau (Ed.), Growing up the Chinese way: Chinese child and adolescent development (pp. 147-167). Hong Kong: The Chinese University Press.

Blackledge, A. (2005). Discourse and power in a multilingual world. In Discourse approaches to politics, society and culture. Amsterdam: John Benjamin Publishing Company.

Blommaert, J., \& Bulcaen, C. (2000). Critical discourse analysis. Annual Review of Anthropology, 29(1), 447-466.

Bond, M. H. (1991). Beyond the Chinese face: Insights from psychology. Hong Kong: Oxford University Press.

Bowers, C. A., \& Flinders, D. J. (1990). Responsive teaching: An ecological approach to classroom patterns of language, culture, and thought. New York: Teachers College Press.

Candela, A. (1999). Students' power in classroom discourse. Linguistics and Education, 10, 139-163.

Chan, K.-L., \& Chan, C. L. W. (2005). Chinese culture, social work education and research. International Social Work, 48, 381-389.

Chanzanagh, H. E., Mansoori, F., \& Zarsazkar, M. (2011). Citizenship values in school subjects: A case-study on Iran's elementary and secondary education school subjects. Procedia-Social and Behavioral Sciences, 15, 3018-3023.

Edwards, D., \& Mercer, N. (1987). Common knowledge: The development of understanding in the classroom. New York: Academic Press.

Erickson, F. (1986). Qualitative methods in research on teaching. In M. C. Wittrock (Ed.), Handbook of research on teaching (3rd ed., pp. 119-159). New York: Macmillan.

Erlandson, D. A., Harris, E. L., Skipper, B. L., \& Allen, S. D. (1993). Doing naturalistic inquiry: A guide to methods. Newbury Park: Sage.

Fairclough, N. (1995). Critical discourse analysis: The critical study of language. New York: Longman.

Fairclough, N. (2003) Analysing discourse: Textual analysis for social research. Psychology Press.

Ferguson, M. R. (2001). Teaching and learning inside the Korean culture. International Educator, 10(2), 16-23.

Foucault, M. (1972). The archeology of knowledge and the discourse on language. New York: Pantheon Books.

Foucault, M. (1980). Power/knowledge: selected interviews and other writings, 1972-1977 (C. Gordon, Ed. \& Trans.). New York: Pantheon. 
Fullan, M. G. (2001). What makes change work for teachers. In F. Banks \& A. S. Mayes (Eds.), Early professional development for teachers (pp. 71-77). London: David Fulton Publishers.

Gao, G., Ting-Toomey, S., \& Gudykunst, W. B. (1996). Chinese communication process. In M. H. Bond (Ed.), The handbook of Chinese psychology (pp. 280-293). Hong Kong: Oxford University Press.

Gee, J. P. (2004). Discourse analysis: What makes it critical? In R. Rogers (Ed.), An introduction to critical discourse analysis in education (pp. 19-50). Mahwah: Lawrence Erlbaum Associates, Publishers.

Gee, J. P. (2005). An introduction to discourse analysis: Theory and method (2nd ed.). New York: Routledge.

Gipps, C., \& MacGilchrist, B. (1999). Primary school learners. In P. Mortimore (Ed.), Understanding pedagogy and its impact on learning (pp. 46-67). London: Paul Chapman Publishing Ltd..

Habermas, J. (1981). New social movements. Telos, 1981(49), 33-37.

Halliday, M. A. K. (1978). Language as social semiotic. London: Arnold.

Halliday, M., \& Matthiessen, C. (2004). An introduction to functional grammar (3rd ed.). London: Edward Arnold.

Hanrahan, M. (2005). Engaging with difference in science classrooms: Using CDA to identify interpersonal aspects of inclusive pedagogy. Critical Studies in Education, 46(2), 107-127.

Hanrahan, M. U. (2006). Highlighting hybridity: A critical discourse analysis of teacher talk in science classrooms. Science Education, 90(1), 8-43.

Ho, D. Y. F., Peng, S. Q., \& Chan, S. F. F. (2001). Authority and learning in Confucian-heritage education. In C. Chiu, F. Salili, \& Y. Hong (Eds.), Multiple competencies and self-regulated learning: Implications for multicultural education (pp. 29-48). Mason: Information Age Publishing Inc..

Hodge, R., \& Kress, G. (1991). Social semiotics. Cambridge: Polity Press; Ithaca: Ithaca, Cornell University Press.

Hong, J., \& Engeström, Y. (2004). Changing principles of communication between Chinese managers and workers. Management Communication Quarterly, 17, 552-585.

Jones, E. E., \& Gerard, H. (1967). Foundations of social psychology. New York: Wiley.

Kennedy, P. (2002). Learning cultures and learning styles: Myth-understandings about adult (Hong Kong) Chinese learners. International journal of lifelong education, 21(5), 430-445.

Kim, Y. (2005). The stories of four schools. Seoul: Mooneumsa.

Kress, G. (1988). Language as social practice. Communication and culture: An introduction, 78-129.

Larsen, M. A. (2010). Troubling the discourse of teacher centrality: A comparative perspective. Journal of Education Policy, 25(2), 207-231.

Lee, K. S. (2006). Korean college students in United States: Perceptions of professors and students. College Student Journal, 40(2), 442-451.

Lee, M.-H., Chang, C.-Y., \& Tsai, C.-C. (2009). Exploring Taiwanese high school students' perceptions of and preferences for teacher authority in the earth science classroom with relation to their attitudes and achievement. International Journal of Science Education, 31, 1811-1830.

Lemke, J. (1990). Talking science: Language, learning, and values. New Jersey: Albex Publishing Corporation.

Leu, Y-C. \& Wu, C-J. (2005). Investigation on an elementary teacher's mathematics pedagogical values through her approach to students' errors. Proceedings of the 29th Conference of the International Group for Psychology of Mathematics Education. Vol. 3 (pp. 249-256). Melbourne: University of Melbourne.

Leung, E. K. (2015). Unveiling" Hidden Stories" behind the Moral and National Education Curriculum Guide (Hong Kong) through Critical Discourse Analysis. International Journal of Learning: Annual Review, 21.

Li, Z.-Z., Carstensen, R., \& Hammen, A. (2007). Comparison of Chinese and American classroom teaching.USChina foreign. Language, 5, 25-29.

Maeng, S., \& Kim, C. (2011). Variations in science teaching modalities and students' pedagogic subject positioning through the discourse register and language code. Science Education, 95(3), 431-457.

Maftoon, P., \& Shakouri, N. (2012). The concept of power in teacher talk: A critical discourse analysis. World Applied Sciences Journal, 19(8), 1208-1215.

Mercer, N. (2000). Words and minds: How we use language to think together. London: Routledge.

Mercer, N., \& Dawes, L. (2008). The value of exploratory talk. In N. Mercer \& S. Hodgkinson (Eds.), Exploring talk in school (pp. 55-71). Cornwall: Mixed Sources.

Nieto, S. (2006). Solidarity, courage and heart: What teacher educators can learn from a new generation of teachers. Intercultural Education, 17, 457-473.

Ochs, E., Schegloff, E. A., \& Thompson, S. A. (Eds.). (1996). Interaction and grammar, Vol. 13. Cambridge: Cambridge University Press.

Park, K. (2005). Mencius (孟子). Seoul: HongIk.

Patton, M. Q. (1990). Qualitative evaluation and research methods (2nd ed.). Newbury Park, CA: Sage.

Pennycook, A. (2001). Critical applied linguistics: A critical introduction. Mahwah: Lawrence Erlbaum Associates, Inc..

Rogers, R. (2004). An introduction to critical discourse analysis in education. In R. Rogers (Ed.), An introduction to critical discourse analysis in education (pp. 1-18). Mahwah: Lawrence Erlbaum Associates, Inc.. 
Shin, S., \& Koh, M.-S. (2007). A cross-cultural study of teacher's beliefs and strategies on classroom behaviour management in urban American and Korean school systems. Education and Urban Society, 39, 286-309.

Strauss, A. (1987). Qualitative analysis for social scientists. Cambridge: Cambridge University Press.

Tannen, D. (1986). That's what I meant!: How conversational style makes or breaks relationships. New York: Ballantine Books.

Taylor, S. (2004). Researching educational policy and change in 'new times': Using critical discourse analysis. Journal of Education Policy, 19(4), 433-451.

Tsui, A. (1996). Reticence and anxiety in second language teaching. In K. Bailey \& D. Nunan (Eds.), Voices from the language classroom (pp. 145-167). Cambridge: Cambridge University Press.

Van Dijk, T. A. (1993). Principles of critical discourse analysis. Discourse \& Society, 4(2), $249-283$.

Van Dijk, T. A. (1996). Discourse, power and access. In C. R. Caldas-Coulthard \& M. Coulthard (Eds.), Texts and practices: Readings in critical discourse analysis (pp. 84-104). London: Routledge.

Van Dijk, T. A. (2001). Critical discourse analysis. In D. Schiffrin, D. Tannen, \& E. Heidi (Eds.), The handbook of discourse analysis (pp. 352-371). Oxford: Blackwell.

Vasara-Hammare, N., Alerby, E., \& Hertting, K. (2012). Education, assessment and the construction of the new Swedish school system. International Journal of Arts \& Sciences, 5(5), 161.

Weiss, G., \& Wodak, R. (2003). Critical discourse analysis: Theory and interdisciplinarity. New York: Palgrave Macmillan.

Wilde, L. (2007). The concept of solidarity: Emerging from the theoretical shadows? British Journal of Politics \& International Relations., 9(1), 171-181.

Wodak, R. (1999). Critical discourse analysis at the end of the 20th century. Research in Language and Social Interaction, 32, 185-193.

Wodak, R. (2001). What CDA is about - A summary of its history, important concepts and its developments. In R. Wodak \& M. Meyer (Eds.), Methods of critical discourse analysis (pp. 1-13). London: Sage Publications.

Wodak, R., \& Meyer, M. (2001). What CDA is about: A summary of its history, important concepts and its developments. In R. Wodak \& M. Meyer (Eds.), Methods of critical discourse analysis (pp. 1-13). London: SAGE Publications Ltd..

Young, R. (1992). Critical theory and classroom talk. Clevedon: Multilingual Matters Ltd..

Yum, J. O. (1988). The impact of Confucianism on interpersonal relationships and communication patterns in East Asia. Communications Monographs, 55(4), 374-388. 